\title{
Carbon Stocks and Fluxes in Rangelands of the Río de la Plata Basin
}

\author{
José M. Paruelo, ${ }^{1,2}$ Gervasio Piñeiro, ${ }^{2}$ Germán Baldi, ${ }^{3}$ Santiago Baeza, ${ }^{4}$ Felipe Lezama, ${ }^{5}$ \\ Alice Altesor, ${ }^{6}$ and Martín Oesterheld ${ }^{1,2}$
}

Authors are ${ }^{1}$ Associated Professors and ${ }^{2}$ Research Scientists, Laboratorio de Análisis Regional y Teledetección, Instituto de Investigaciones Fisiológicas y Ecológicas vinculadas a la Agricultura, and Facultad de Agronomía, Universidad de Buenos Aires, and Consejo Nacional de Investigaciones Científicas y Técnicas (CONICET), Buenos Aires, Argentina; ${ }^{3}$ Research Assistant, Grupo de Estudios Ambientales, Instituto de Matemática Aplicada San Luis, Universidad Nacional de San Luis-CONICET, San Luis, Argentina; ${ }^{4}$ Research Assistant and ${ }^{6}$ Assistant Professor, Sección Ecología Terrestre, Facultad de Ciencias, Universidad de la República, Montevideo, Uruguay; and ${ }^{5}$ Research Scientist, Instituto Nacional de Investigaciones Agropecuarias, Treinta y Tres, Uruguay.

\begin{abstract}
Grasslands are one of the most modified biomes on Earth. Land use changes had a large impact on carbon (C) stocks of grasslands. Understanding the impact of land use/land cover changes on C stocks and fluxes is critical to evaluate the potential of rangeland ecosystem as $\mathrm{C}$ sinks. In this article we analyze $\mathrm{C}$ stocks and fluxes across the environmental gradients of one of the most extensive temperate rangeland areas: the Río de la Plata Grasslands (RPG) in South America. The analysis summarizes information provided by field studies, remote sensing estimates, and modeling exercises. Average estimates of aboveground net primary production (ANPP) ranged from 240 to $316 \mathrm{~g} \mathrm{C} \cdot \mathrm{m}^{-2} \cdot \mathrm{yr}^{-1}$. Estimates of belowground NPP (BNPP) were more variable than ANPP and ranged from 264 to $568 \mathrm{~g} \mathrm{C} \cdot \mathrm{m}^{-2} \cdot \mathrm{yr}^{-1}$. Total Carbon ranged from 5004 to $15008 \mathrm{~g} \mathrm{C} \cdot \mathrm{m}^{-2}$. Plant biomass contribution to Total Carbon averaged $13 \%$ and varied from $9.5 \%$ to $27 \%$ among sites. The largest plant $\mathrm{C}$ stock corresponded to belowground biomass. Aboveground green biomass represented less than $7 \%$ of the plant C. Soil organic carbon (SOC) was concentrated in the slow and passive compartments of the organic matter. Active soil pool represented only $6.7 \%$ of the SOC. The understanding of C dynamics and stocks in the RPG grasslands is still partial and incomplete. Field estimates of ANPP and BNPP are scarce, and they are not based on a common measurement protocol. Remotely sensed techniques have the potential to generate a coherent and spatially explicit database on ANPP. However, more work is needed to improve estimates of the spatial and temporal variability of radiation use efficiency. The absence of a flux tower network restricts the ability to track seasonal changes in $\mathrm{C}$ uptake and to understand fine-scale controls of $\mathrm{C}$ dynamics.
\end{abstract}

\section{Resumen}

Los pastizales son uno de los ecosistemas terrestres que más modificaciones han sufrido. Los cambios en el uso del suelo han tenido un gran impacto sobre los depósitos y flujos de C. Comprender el impacto de los cambios en uso y cobertura del suelo es crítico a la hora de evaluar el potencial de los pastizales de retener C. En este trabajo analizamos los flujos y depósitos de C a lo largo de los gradientes ambientales de una de las áreas de pastizales templados más extendidas: los Pastizales del Río de la Plata en Sudamérica. El análisis resume la información provista por estudios de campo, teledetección y simulaciones con modelos. La Productividad Primaria Neta Aérea (PPNA) varió entre 240 y $316 \mathrm{~g} \mathrm{C} \cdot \mathrm{m}^{-2} \cdot$ año $^{-1}$. La PPN subterránea fue más variable que la PPNA, cubriendo un rango de valores entre 264 y $568 \mathrm{~g} \mathrm{C} \cdot \mathrm{m}^{-2} \cdot$ año $^{-1}$. El C total varió entre 5004 y $15008 \mathrm{~g} \mathrm{C} \cdot \mathrm{m}^{-2}$. En promedio, un $13 \%$ de ese C correspondió a biomasa vegetal. La contribución de la biomasa vegetal varió entre $9.5 \%$ y $27 \%$. El depósito de C vegetal más importante fue el subterráneo. La biomasa verde aérea representó menos de un 7\% del C vegetal. El C orgánico del suelo (COS) se concentró en los compartimentos pasivos y de dinámica lenta. El depósito activo de la materia orgánica edáfica representó sólo el $6.7 \%$ del COS. El conocimiento de la dinámica y los depósitos de C en la región es aún parcial e incompleto. Las estimaciones de PPNA y PPNB son escasas y no se basan en un protocolo de medición común. Las técnicas de teledetección tienen el potencial para generar una base de datos de PPNA consistente y espacialmente explícita. Sin embargo, es necesario mejorar las estimaciones de la variabilidad espacial y temporal de la eficiencia en el uso de la radiación. La falta de una red de torres de medición de flujos restringe la posibilidad de monitorear cambios estacionales en las ganancias de $\mathrm{C}$ y de entender los controles de la dinámica del $\mathrm{C}$ a escala detallada.

Key Words: aboveground net primary production, belowground net primary production, Century model, land use/land cover changes, remote sensing

Research was partially funded by CONICET (PIP 5961), FONCYT (PICT 32399 and 32415), UBACYT (CS 6179/05 G 078 and G 071) (Argentina), INIA-FPTA 175 (Uruguay), and SENSOR-TTC 0038742 (Uruguay and Argentine partners), and by a grant from the Inter-American Institute for Global Change Research (III, CRN II 2031), which is supported by the US National Science Foundation (Grant GEO-0452325).

This publication was made possible through support provided to the Global Livestock Collaborative Research Support Program by the Office of Agriculture, Bureau for Economic Growth, Agriculture and Trade, United States Agency for International Development under terms of Grant No. PCE-G-00-98-00036-00. The opinions expressed herein are those of the author(s) and do not necessarily reflect the views of the USAID.

Correspondence: José Paruelo, Laboratorio de Análisis Regional y Teledetección, Departamento de Métodos Cuantitativos y Sistemas de Información, IFEVA, Facultad de Agronomía, and CONICET, Universidad de Buenos Aires, Av San Martín 4453, (1417) Ciudad de Buenos Aires, Argentina. Email: paruelo@agro.uba.ar

Manuscript received 17 March 2008; manuscript accepted 3 April 2009. 


\section{INTRODUCTION}

The broad range of environmental conditions where grasslands can be found determines important spatial differences in ecosystem structure and functioning. Differences in structure are mainly associated with changes in the relative abundance of plant functional types, particularly the proportion of $\mathrm{C}_{3}$ and $\mathrm{C}_{4}$ grasses (Paruelo and Lauenroth 1996) or changes in the size of carbon (C) and nitrogen (N) pools (Burke et al. 1989). Functional differences derive from different patterns of exchange of matter and energy between the biota and the atmosphere. Carbon dynamics is an integrative descriptor of ecosystem functioning, the main determinant of the energy available for the trophic web, and a major control of their utilization by humans.

Grasslands are one of the most modified biomes on Earth, because a large portion of them has been replaced by crop fields or is subject to livestock grazing (Hannah et al. 1995). Land use changes include the replacement of the original cover by annual or perennial crops and the intensification of biomass removal by domestic herbivores (Meyer and Turner 1994). Both changes had a large impact on C stocks (Burke et al. 1989; Milchunas and Lauenroth 1993; Álvarez et al. 1998; Álvarez 2001; Piñeiro et al. 2006b, 2009) and C gains (Oesterheld et al. 1999; Paruelo et al. 2000; Guerschman and Paruelo 2005). Understanding the impact of land use and land cover changes on $\mathrm{C}$ stocks and fluxes is critical to evaluate the potential of rangeland ecosystem as $\mathrm{C}$ sinks (Lal 2004).

Soil organic carbon (SOC) and net primary production (NPP) are two key attributes of the grassland $\mathrm{C}$ cycle and energy flux. NPP is a major determinant of SOC, and, conversely, SOC may determine NPP both in the mid- and the long term through its link with nutrient pools. The recalcitrant forms of $\mathrm{C}$ compounds in grasslands soils are an effective way for $\mathrm{C}$ sequestration (Lal 2004). Resource allocation between aboveand belowground organs and the vertical distribution of belowground biomass are the main determinants of SOC distribution in the profile (Jobbágy and Jackson 2000).

A better understanding of the spatial patterns and environmental controls of $\mathrm{C}$ stocks and fluxes in South American grasslands would not only improve our regional understanding of $\mathrm{C}$ dynamics but also explore the behavior of $\mathrm{C}$ fluxes under environmental conditions not present in Northern Hemisphere grasslands. Paruelo et al. (1998) found that for some ecosystem attributes (plant functional traits, relative abundance, NPP, SOC stocks, carbon gain dynamics) the environmental controls were similar in biogeographically unrelated areas of North and South America. The study suggested the existence of an important degree of convergence at regional scales in both functional and structural attributes. It also pointed out differences and biases in the regional patterns of some attributes that require further analyses. For example, South American grasslands differ from North American ones in some climatic features (e.g., thermal amplitude; Paruelo et al. 1995; Lauenroth et al. 2004) and in the evolutionary history of grazing (Milchunas et al. 1988). A description of ecosystem processes in a broader range of environmental conditions becomes particularly important in a context of global changes because it provides a basis on which to forecast the consequences of environmental change.
In this article we analyze patterns of $\mathrm{C}$ fluxes and stocks along the environmental gradients of one of the most extensive temperate rangeland areas: the Río de la Plata Grasslands (RPG) in South America. We characterized C fluxes (particularly net primary production) and $\mathrm{C}$ stocks across environmental gradients using a combination of field studies, modeling (Century), databases, and remote sensing approaches. We also analyzed the environmental controls of $\mathrm{C}$ stocks and gains and the impact of disturbance on them. Our analysis summarizes published data and generates new estimates for some processes over the entire region to elaborate a regional $\mathrm{C}$ balance. Such balance provides a reference situation to evaluate the extent and quality of our regional knowledge on $\mathrm{C}$ dynamics and the impact of management practices on it.

\section{MATERIALS AND METHODS}

\section{Study Site: The RPG}

The RPG extend between $28^{\circ}$ and $38^{\circ}$ latitude covering ca. $700000 \mathrm{~km}^{2}$ (Fig. 1) of eastern Argentina, Uruguay, and southern Brazil (Soriano 1991; Paruelo et al. 2007). Woody vegetation within the region is circumscribed only to small areas near water bodies, such as gallery forests along the large Paraná and Uruguay rivers and their tributaries. The main climatic gradients of RPG occur along a southwest-northeast axis. Mean annual precipitation (MAP) increases from $600 \mathrm{~mm}$ to $1500 \mathrm{~mm}$ and mean annual temperature from $13^{\circ} \mathrm{C}$ to $21^{\circ} \mathrm{C}$ from the SW to the NE extremes of the gradient. The whole region is characterized by a lack of a clear seasonality in precipitation. Along a west-east gradient, the soils developed on quaternary sediments shift from mollic Entisols with incipient horizon differentiation to well-developed Mollisols with high clay accumulation in subsurface horizons (Instituto Nacional de Tecnología Agropecuaria 1989). In general these soils have high organic matter content and base saturation posing little or no constrains for agriculture. The widespread areas of low and flat topography are characterized by sodic and/or hydromorphic soils (natric and aquic Mollisols to Alfisols). In the Uruguayan and Brazilian parts of the RPG, a more complex array of parent materials and topographic forms translated into higher soil heterogeneity. Although welldeveloped Mollisols similar to those of the eastern Pampas are frequent in this region, widespread shallow soils over rock outcrops (Entisols) and profiles with poor base saturation are a distinctive feature (Alfisols, Inceptisols, and Oxisols in the northern edge of the region; Durán 1991).

Steppes and prairies, though modified by grazing, still cover most of the area, mainly in the Uruguayan and Brazilian Campos and the Flooding Pampa in Argentina. Grasslands are co-dominated by $\mathrm{C}_{3}$ and $\mathrm{C}_{4}$ grasses, and woody species are less important than the herbaceous component. The major internal subdivisions of the RPG are based on geomorphic, hydrologic, and edaphic features and their linkage with natural vegetation and land use (Fig. 1; Soriano 1991).

The replacement of natural vegetation by crops in the RPG started at the beginning of the 20th century with increasing European immigration (Hall et al. 1992). Three main land use changes can be identified: replacement of grasslands by annual and forage crops, replacement of grasslands by tree plantations, 


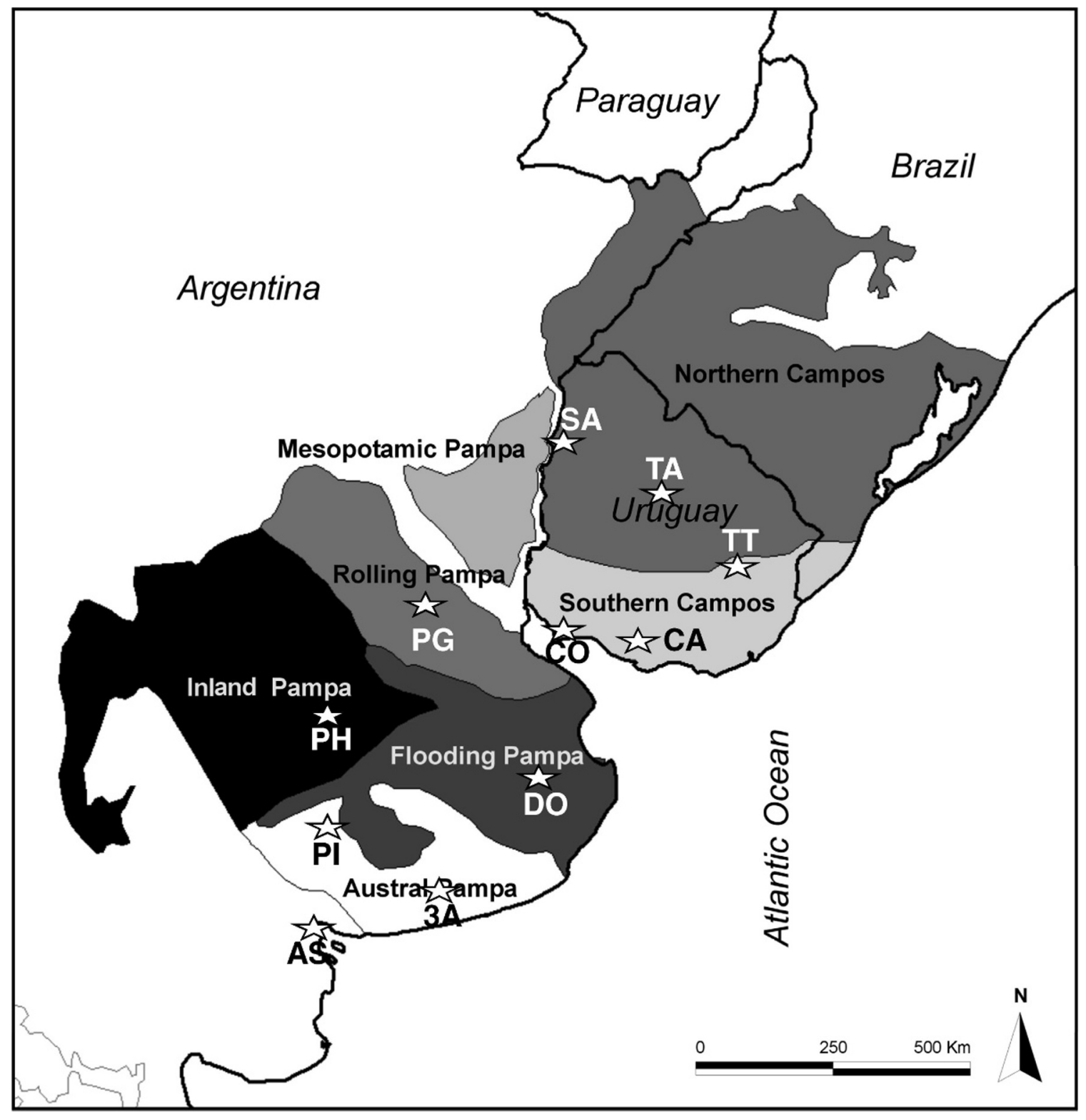

Figure 1. Río de la Plata grasslands and their main phytogeographic units. Stars correspond to the sites included in the simulation analysis. SA indicates Salto; TA, Tacuarembó; TT, Treintra y Tres; CA, Canelones; C0, Colonia; PG, Pergamino, D0, Dolores; PH, Pehuajó; PI, Pigué; 3A, Tres Arroyos; and AS, Ascasubi.

and intensification of grazing in native prairies. The spatial variability of cropped area is associated with soil restrictions. For example, sodicity and hydromorphism constrain agriculture in the Flooding Pampa, whereas soil depth becomes limiting in parts of the Uruguayan Campos. Agriculture has strongly impacted the Rolling, Inland, and Southern Pampas in such a way that natural vegetation is unknown and probably poorly represented in what might be considered relict areas. Afforestation of some of the most productive native grasslands of the continent is already increasing rapidly and will probably be reinforced by the prospective carbon sequestration market (Jobbágy et al. 2005). Grazing is the main cause of vegetation changes in nonagricultural areas. Domestic herbivores, introduced in the 16 th century, profoundly modified the structure and functioning of the grasslands (Rusch and Oesterheld 1997; Rodríguez et al. 2003; Altesor et al. 2005, 2006; Piñeiro et al. 2006b; see article by Piñeiro et al. in this issue).

In a recent study, Baldi and Paruelo (2008) performed a detailed land use and land cover characterization based on Landsat Thematic Mapper and Enhanced Thematic Mapper Plus images for eight pilot areas along the RPG (Fig. 2) and for the first years of the century (2000-2004). The study included approximately $265000 \mathrm{~km}^{2}$ of the $750000 \mathrm{~km}^{2}$ of the grassland system, incorporating its physical and ecological internal heterogeneity. The results indicated that rangelands, including sown pastures, covered $61.4 \%$ of the territory and annual crops $25.9 \%$. The spatial patterns of land use and land cover were closely related to a few edaphic and topographic 


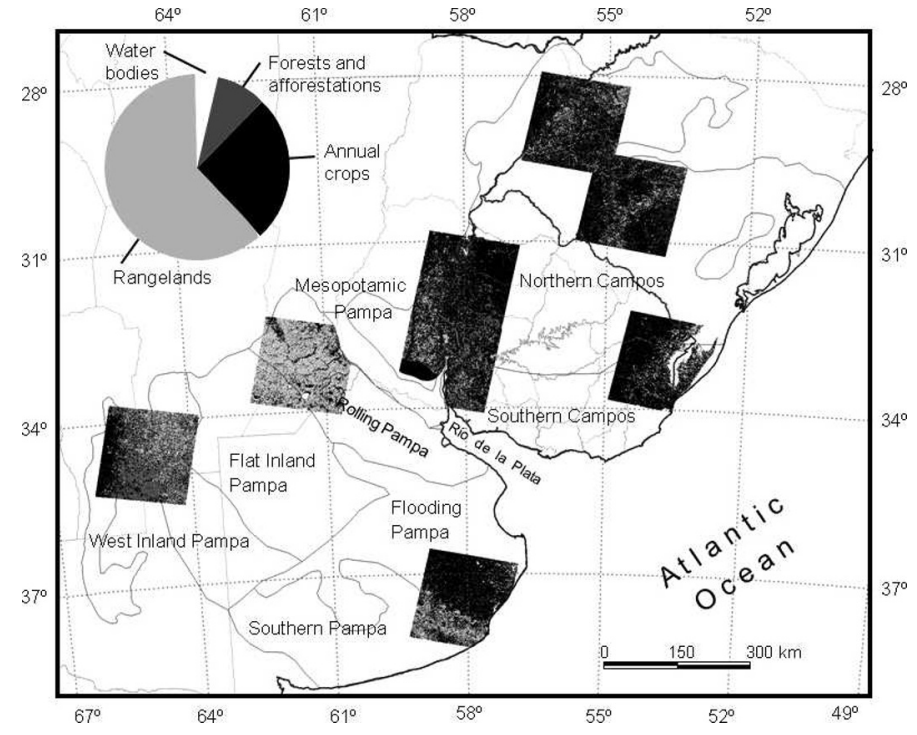

Figure 2. Land use/land cover distribution (annual crops, rangelands, and forest +afforestations) in eight Landsat scenes. Based on Baldi (2007) and Baldi and Paruelo (2008) for 2000-2004. The pie chart presents the relative proportion of the different units within the scenes.

characteristics, including drainage conditions, soil depth, or terrain slope (Baldi et al. 2006; Baldi 2007).

\section{Field Estimates of Carbon Gains}

$\mathrm{C}$ gains may be estimated from biomass data taken in the field. In general, field studies provide estimates of aboveground NPP (ANPP; mass of C or dry matter accumulated per unit of area and time). We compiled a dataset of site specific ANPP estimates derived from biomass harvesting for the whole region. Data were obtained from published articles and technical reports (Table 1).

The most common approach to estimate belowground NPP (BNPP) is based on belowground biomass sampling and on adding positive changes in biomass through time. Data on BNPP based on this approach were compiled for the whole region.

\section{Remote Sensing Estimates of C Gains}

We estimated ANPP over the entire region using the Monteith (1972) model. This model states that the NPP (or ANPP) of a canopy is positively and linearly related to the total amount of photosynthetic active radiation (PAR; MJ) absorbed by green tissues (APAR) during the growing season:

$$
\mathrm{ANPP}=\int \mathrm{APAR} \cdot \varepsilon
$$

The proportionality constant $(\varepsilon)$ is a measure of the radiation use efficiency (RUE; mass $\mathrm{C}$ or $\mathrm{DM} \cdot \mathrm{MJ}^{-1}$ ). APAR results from the product of the incoming radiation (PAR) and the fraction of PAR absorbed by green tissues (fAPAR). fAPAR is positively related to spectral indices derived from the reflectance in the red and infrared portion of the electromagnetic spectrum, such as the Normalized Difference Vegetation Index (NDVI; Rouse et al. 1973) or the Enhanced Vegetation Index (EVI; Asrar et al. 1984; Sellers et al. 1992; Huete et al. 2002).

For the eight phytogeographic subunits of the RPG we estimated the fraction of the PAR absorbed by the green canopy (fAPAR), the total amount of PAR absorbed (APAR), and the ANPP of rangelands (native grasslands and implanted perennial pastures). Rangelands were identified using the land cover maps generated by Baldi et al. (2006) and Baldi and Paruelo (2008; Fig. 2). In each subunit we selected 25 polygons corresponding to rangelands. Each polygon was superimposed on temporal series of EVI images provided by the MODIS sensor. EVI is an improved spectral index similar to the NDVI, but with lower saturation at high levels of leaf area index and less sensitivity to the soil signal (Justice et al. 2002). The "MODIS Land Science Team" (http://modis-land.gsfc.nasa. gov) generates EVI images every 16 days with a spatial resolution of $250 \times 250 \mathrm{~m}$. We used data from two MODIS scenes (h12v12 y h13v12) for the 2000-2006 period. Each polygon included 12-14 MODIS pixels. For each subunit of the RPG we extracted approximately 350 MODIS pixels. ANPP was estimated using the Monteith (1972) model (see above), and PAR data were obtained from http://www.ntsg.umt.edu/ cgi-bin/show_good_ncdc_stations.pl. fPAR was calculated from EVI using a linear model (Ruimy et al. 1994; Piñeiro et al. 2006a). Radiation use effciency ( $\varepsilon a)$ for each month was estimated from the empirical values provided by Piñeiro et al. (2006a) for rangelands of the region.

\section{Modeling Estimates of C Fluxes and Stocks: The Century Model}

In grassland areas simulation approaches have been dominated by the use of a biogeochemical model developed specifically for grassland areas: Century (Parton et al. 1987). Soil organic matter is divided in the Century model into three different pools: active, slow, and passive (recalcitrant organic matter), with turnover times of 1-5 yr, 20-40 yr, and 100-1000 yr, respectively. Surface microbial activity is simulated, and litter is divided into belowground and surface pools as well as into structural and metabolic components (Parton et al. 1987). Soil fluxes are controlled by environmental variables (temperature, water, and texture) and by lignin: $\mathrm{N}$ and $\mathrm{C}: \mathrm{N}$ ratios. Above and belowground plant production is simulated based on water, nutrient, and shading factors. The Century model may simulate different episodic events such as fire, fertilizations, grazing, plowing, or irrigation. The model simulates carbon, N, water, phosphorus, and sulfur dynamics.

We used Century model simulation results generated by Piñeiro et al. (2006b). The model was calibrated and evaluated for 11 sites distributed across the main environmental gradient of the region (Fig. 2). The simulation, planned to evaluate the impact of grazing on the grasslands, incorporated a number of assumptions. They simulated $8000 \mathrm{yr}$ of grazing by native herbivores followed by $370 \mathrm{yr}$ of grazing by domestic herbivores. The first $8000 \mathrm{yr}$ served to stabilize soil organic matter pools at each site and provided a reference to contrast with the following $370 \mathrm{yr}$. This simulation had the following assumptions:

1) Stable vegetation structure and species composition during the simulation period 
Table 1. Estimates of aboveground net primary production (ANPP) available for the Río de la Plata Grassland (RPG) region. Estimates correspond to published data and technical reports. The ANPP range presented in the last column corresponds to interannual variability in ANPP. Climatic data (MAP, mean annual precipitation; MAT, mean annual temperature) were obtained from Hijmans et al. (2005). ${ }^{1}$

\begin{tabular}{|c|c|c|c|c|c|c|c|c|}
\hline Source & $\begin{array}{c}\mathrm{RPG} \\
\text { subunit }\end{array}$ & System & Lat & Long & $\begin{array}{l}\text { MAP } \\
(\mathrm{mm})\end{array}$ & $\begin{array}{l}\text { MAT } \\
\left({ }^{\circ} \mathrm{C}\right)\end{array}$ & $\begin{array}{c}\text { Average ANPP } \\
\left(\mathrm{kg} \cdot \mathrm{ha}^{-1}\right. \\
\left.\mathrm{yr}^{-1}\right)\end{array}$ & $\begin{array}{c}\text { ANPP Range } \\
\left(\mathrm{kg} \cdot \mathrm{ha}^{-1} .\right. \\
\left.\mathrm{yr}^{-1}\right)\end{array}$ \\
\hline \multirow{2}{*}{$\begin{array}{l}\text { Bemhaja and Olmos } \\
\text { (1996) }\end{array}$} & NC & Native grasslands on uplands, sandy soils & $31^{\circ} 35^{\prime}$ & $55^{\circ} 41^{\prime}$ & 1290 & 18.1 & 5144 & \\
\hline & NC & Native grasslands on lowlands & $31^{\circ} 35^{\prime}$ & $55^{\circ} 41^{\prime}$ & 1290 & 18.1 & 5503 & \\
\hline \multirow{3}{*}{$\begin{array}{l}\text { Berreta and } \\
\text { Bemhaja (1998) }\end{array}$} & NC & Native grasslands on shallow soils & $32^{\circ} 00^{\prime}$ & $57^{\circ} 09^{\prime}$ & 1239 & 18.1 & 2885 & $1412-4835$ \\
\hline & NC & Native grasslands on shallow soils & $32^{\circ} 00^{\prime}$ & $57^{\circ} 09^{\prime}$ & 1239 & 18.1 & 3772 & $2330-5443$ \\
\hline & NC & Native grasslands on deep soils & $32^{\circ} 00^{\prime}$ & $57^{\circ} 09^{\prime}$ & 1239 & 18.1 & 4576 & $3204-6646$ \\
\hline \multirow[t]{3}{*}{ Pizzio (2001) } & NC & Native grassland on sandy soils & $29^{\circ} 11^{\prime}$ & $58^{\circ} 04^{\prime}$ & 1243 & 19.9 & 5086 & $3400-8100$ \\
\hline & NC & Native grassland on deep soils & $29^{\circ} 11^{\prime}$ & $58^{\circ} 04^{\prime}$ & 1243 & 19.9 & 5906 & \\
\hline & NC & Native grassland on shallow soils & $29^{\circ} 11^{\prime}$ & $58^{\circ} 04^{\prime}$ & 1243 & 19.9 & 2796 & \\
\hline \multirow[t]{3}{*}{ Saldanha (2005) } & NC & Native grasslands on deep soils & $31^{\circ} 41^{\prime}$ & $57^{\circ} 42^{\prime}$ & 1274 & 18.3 & 5929 & \\
\hline & NC & Native grasslands on deep soils & $31^{\circ} 41^{\prime}$ & $57^{\circ} 42^{\prime}$ & 1274 & 18.3 & 5525 & \\
\hline & NC & Native grasslands on deep soils & $31^{\circ} 23^{\prime}$ & $57^{\circ} 42^{\prime}$ & 1274 & 18.3 & 4791 & \\
\hline \multirow[t]{10}{*}{ Platero et al. (2001) } & NC & Native grassland & $31^{\circ} 04^{\prime}$ & $56^{\circ} 01^{\prime}$ & 1400 & 17.8 & 3273 & $2120-4959$ \\
\hline & NC & Native grassland & $31^{\circ} 04^{\prime}$ & $56^{\circ} 01^{\prime}$ & 1400 & 17.8 & 3224 & $2269-4060$ \\
\hline & NC & Native grassland & $31^{\circ} 00^{\prime}$ & $56^{\circ} 00^{\prime}$ & 1406 & 18.0 & 4205 & $2912-6683$ \\
\hline & NC & Native grassland & $31^{\circ} 00^{\prime}$ & $56^{\circ} 00^{\prime}$ & 1406 & 18.0 & 3869 & $2053-6847$ \\
\hline & $\mathrm{SC}$ & Native grassland & $32^{\circ} 34^{\prime}$ & $56^{\circ} 52^{\prime}$ & 1178 & 17.6 & 6050 & $5196-10483$ \\
\hline & NC & Pasture & $31^{\circ} 04^{\prime}$ & $56^{\circ} 01^{\prime}$ & 1400 & 17.8 & 8089 & $6990-9890$ \\
\hline & NC & Pasture & $31^{\circ} 04^{\prime}$ & $56^{\circ} 01^{\prime}$ & 1400 & 17.8 & 4189 & $3269-4967$ \\
\hline & NC & Pasture & $31^{\circ} 00^{\prime}$ & $56^{\circ} 00^{\prime}$ & 1406 & 18 & 9772 & $5403-12629$ \\
\hline & NC & Pasture & $31^{\circ} 00^{\prime}$ & $56^{\circ} 00^{\prime}$ & 1406 & 18 & 7229 & $5416-10249$ \\
\hline & SC & Pasture & $32^{\circ} 34^{\prime}$ & $56^{\circ} 52^{\prime}$ & 1178 & 17.6 & 5760 & $2816-6009$ \\
\hline \multirow[t]{3}{*}{ Altesor et al. (2005) } & $\mathrm{SC}$ & Native grassland on Argiudolls, grazed & $34^{\circ} 19^{\prime}$ & $57^{\circ} 02^{\prime}$ & 1185 & 17.1 & 6020 & \\
\hline & $\mathrm{SC}$ & Native grassland on Argiudolls, clipped & $34^{\circ} 19^{\prime}$ & $57^{\circ} 02^{\prime}$ & 1185 & 17.1 & 7770 & \\
\hline & $\mathrm{SC}$ & Native grassland on Argiudolls, exclosures & $34^{\circ} 19^{\prime}$ & $57^{\circ} 02^{\prime}$ & 1185 & 17.1 & 3980 & \\
\hline Formoso (2001) & SC & Native grasslands on deep soils & $33^{\circ} 52^{\prime}$ & $55^{\circ} 34^{\prime}$ & 1285 & 16.6 & 4218 & $2314-6061$ \\
\hline $\begin{array}{l}\text { Bermúdez and } \\
\text { Ayala (2005) }\end{array}$ & SC & Native grassland on Argiudolls, grazed & $33^{\circ} 15^{\prime}$ & $54^{\circ} 28^{\prime}$ & 1253 & 17.3 & 3425 & $1192-5245$ \\
\hline \multirow{2}{*}{$\begin{array}{l}\text { Deregibus et al. } \\
\text { (1985) }\end{array}$} & MeP & Native grassland on Vertisols & $31^{\circ} 42^{\prime}$ & $58^{\circ} 47^{\prime}$ & 1121 & 18.3 & 5573 & \\
\hline & $\mathrm{MeP}$ & Native grassland on Argialbols & $31^{\circ} 48^{\prime}$ & $58^{\circ} 56^{\prime}$ & 1121 & 18.3 & 4864 & \\
\hline Sala et al. (1981) & $\mathrm{FP}$ & Native grasslands on Natraquolls & $36^{\circ} 30^{\prime}$ & $58^{\circ} 30^{\prime}$ & 909 & 14.9 & 5320 & \\
\hline \multirow{3}{*}{$\begin{array}{l}\text { Oesterheld and } \\
\text { León (1987) }\end{array}$} & $\mathrm{FP}$ & Sowed pastures $2 \mathrm{yr}$ old on Argiudolls & $35^{\circ} 06^{\prime}$ & $57^{\circ} 32^{\prime}$ & 967 & 16.2 & 8760 & \\
\hline & RoP & Sowed pastures $5 \mathrm{yr}$ old on Argiudolls & $35^{\circ} 06^{\prime}$ & $57^{\circ} 32^{\prime}$ & 967 & 16.2 & 7300 & \\
\hline & RoP & Sowed pastures 13 yr old on Argiudolls & $35^{\circ} 06^{\prime}$ & $57^{\circ} 32^{\prime}$ & 967 & 16.2 & 8760 & \\
\hline \multirow{3}{*}{$\begin{array}{l}\text { Rusch and } \\
\text { Oesterheld (1997) }\end{array}$} & FP & Native grassland on Natraquolls, exclosures & $36^{\circ} 30^{\prime}$ & $58^{\circ} 30^{\prime}$ & 909 & 14.9 & 7200 & \\
\hline & FP & Native grassland on Natraquolls, mowed & $36^{\circ} 30^{\prime}$ & $58^{\circ} 30^{\prime}$ & 909 & 14.9 & 5700 & \\
\hline & $\mathrm{FP}$ & Native grassland on Natraquolls, grazed & $36^{\circ} 30^{\prime}$ & $58^{\circ} 30^{\prime}$ & 909 & 14.9 & 2250 & \\
\hline \multirow{4}{*}{$\begin{array}{l}\text { Hidalgo and } \\
\text { Cahuépé (1991) }\end{array}$} & $\mathrm{FP}$ & Native grassland on Argiudolls & $38^{\circ} 45^{\prime}$ & $57^{\circ} 57^{\prime}$ & 758 & 8.4 & 7450 & \\
\hline & FP & Native grassland on Natraquolls & $38^{\circ} 45^{\prime}$ & $57^{\circ} 57^{\prime}$ & 758 & 8.4 & 5500 & \\
\hline & $\mathrm{FP}$ & Native grassland on Argialbolls & $38^{\circ} 45^{\prime}$ & $57^{\circ} 57^{\prime}$ & 758 & 8.4 & 6600 & \\
\hline & FP & Native grassland on Natraqualfs & $38^{\circ} 45^{\prime}$ & $57^{\circ} 57^{\prime}$ & 758 & 8.4 & 2100 & \\
\hline \multirow{3}{*}{$\begin{array}{l}\text { Perez and Frangi } \\
(2000)\end{array}$} & AuP & Mountain grasslands, low elevation & $38^{\circ} 01^{\prime}$ & $62^{\circ} 02^{\prime}$ & 857 & 10.8 & 4620 & \\
\hline & AuP & Mountain grasslands, intermediate elevation & $38^{\circ} 01^{\prime}$ & $62^{\circ} 02^{\prime}$ & 857 & 10.8 & 5850 & \\
\hline & AuP & Mountain grasslands, high elevation & $38^{\circ} 01^{\prime}$ & $62^{\circ} 02^{\prime}$ & 857 & 10.8 & 3780 & \\
\hline
\end{tabular}

${ }^{1}$ NC indicates Northern campos; SC, Southern Campos; FP, Flooding Pampa; RoP, Rolling Pampa; AuP, Austral Pampa; and MeP, Mesopotamic Pampa.

2) Native herbivore grazing during soil stabilization and domestic herbivore grazing at increasing stocking rates from 1600 through 1970 with logistical growth curve

3) No direct short-term effect of grazing on ANPP or root/ shoot partitioning
4) Constant $\mathrm{N}$ deposition through time, but variable among sites in direct relationship with annual precipitation

5) $\mathrm{N}$ returns in urine and dung set to $70 \%$ of consumed $\mathrm{N}$

6) C respired by livestock estimated as the inverse of the digestibility of consumed biomass, which varied according to the $\mathrm{C} 4: \mathrm{C} 3$ ratio of each site 
7) Constant atmospheric $\mathrm{CO}_{2}$ concentration ( $\left.~ 300 \mathrm{ppm}\right)$

8) No fire events either before or after herbivore introduction

9) Constant climate (present conditions based on records of approximately the last $60 \mathrm{yr}$ ).

\section{RESULTS AND DISCUSSION}

\section{Carbon Fluxes and Stocks}

C Gains: Field Data. ANPP estimates based on harvested biomass data are scarce, probably because of the amount of work involved in collecting and processing the data. For the entire region we were able to compile a database of only 14 studies that estimate ANPP from harvest data for 41 sites/ systems (Table 1). The estimates covered in general 1-3 yr. The site with the longest record was located in the Northern Campos (Mercedes, Corrientes, Argentina) and covered a period of $19 \mathrm{yr}$. Average estimates of ANPP ranged from $2100 \mathrm{~kg} \cdot \mathrm{ha}^{-1} \cdot \mathrm{yr}^{-1}$ to $9772 \mathrm{~kg} \cdot \mathrm{ha}^{-1} \cdot \mathrm{yr}^{-1}$ (average ANPP for all the available sites/situations $=5347 \pm 1794 \mathrm{~kg} \cdot \mathrm{ha}^{-1}$. $\mathrm{yr}^{-1}$ ). Assuming a $\mathrm{C}$ proportion of 0.45 for herbaceous biomass, average ANPP would be $241 \mathrm{~g} \mathrm{C} \cdot \mathrm{m}^{-2} \cdot \mathrm{yr}^{-1}$. Those sites with more than 1 yr of data showed important interannual variability in ANPP. On average the observed range of ANPP (maximum-minimum values) was equivalent to $80 \%$ of the mean production of the site.

The use of biomass data (a state variable) to infer ANPP (a flux) is far from straightforward and strongly relies on assuming that all biomass produced during a given period may be accounted for by one or more biomass harvests (e.g., herbivory and decay is negligible; Oesterheld and McNaughton 2000; Sala and Austin 2000). There is a large diversity of approaches to deal with cases where this sort of assumption is questionable (e.g., sequential harvests, sorting material by species and compartments, enclosures or moving cages), which results in different estimates of ANPP depending on the chosen approach (McNaughton et al. 1996; Scurlock et al. 2002). The often high variability of biomass within plant communities increases the number of replicate samples required to reach reasonable accuracy (Eckblad 1991). Several of the approaches mentioned in the previous paragraph to deal with the unaccounted loss of biomass between harvests require more frequent sampling and the sampling of different compartments, whose variability is usually larger than the variability of the whole. As a result, several double-sampling techniques have been developed ('t Mannetje and Haydock 1963; Tucker 1980) and considered in some of the studies included in our analysis. Additionally, the various available approaches to calculate ANPP from biomass compartments may produce widely different estimates based on the same harvest (Scurlock et al. 2002). The exclusion of herbivores to deal with the loss of biomass that would alter the estimates modifies the structure of the canopy whose productivity is being estimated. As grazing affects ANPP, its exclusion for methodological reasons may often result in a poor estimate of the productivity of the grazed situation that needs to be evaluated (McNaughton et al. 1996; Oesterheld and McNaughton 2000).

BNPP data are even scarcer. Three experimental studies presented data for the Flooding and the Austral Pampa: Doll
(1991), $3800-8200 \mathrm{~kg} \cdot \mathrm{ha}^{-1} \cdot \mathrm{yr}^{-1}$; de Wysiecky and Perez (1994), $5600-5650 \mathrm{~kg} \cdot \mathrm{ha}^{-1} \cdot \mathrm{yr}^{-1}$; and Perez and Frangi (2000), 6 690-7 $790 \mathrm{~kg} \cdot \mathrm{ha}^{-1} \cdot \mathrm{yr}^{-1}$. These showed, as have many others in temperate grasslands (Gill et al. 2002; Pucheta et al. 2004; Hui and Jackson 2005), that BNPP is, in general, higher than ANPP (BNPP/NPP =0.47-0.87, Hui and Jackson 2005). BNPP is one of the poorest understood attributes of the ecosystem (Milchunas and Lauenroth 1992). Estimates of the BNPP:NPP ratios varied widely, and a large proportion of such variation is due to methodological issues (Lauenroth 2000). No direct approach allows us to estimate BNPP in the field. BNPP in a given time interval includes the biomass accumulated, the herbivore consumption, the biomass lost as exudation, and death. In grassland ecosystems the absence of large woody roots makes it simpler than in forests to estimate BNPP. However, to discriminate between live and dead tissues, to exclude or quantify herbivore consumption, or to quantify root exudates represent major challenges to quantify root biomass. Ingrowth cores, isotopic analyses (based on ${ }^{14} \mathrm{C}$ dilution), minirhizotrons, and $\mathrm{C}$ balances are some of the alternatives used to estimate BNPP (Lauenroth 2000).

C Gains: Remotely Sensed Data. The rangelands of the different subunits of the RPG showed three general patterns of seasonal change of fAPAR (Fig. 3a, b, c). The northernmost subunits (Northern and Southern Campos and Mesopotamic Pampa) showed a relatively low intra-annual variability of fAPAR (Fig. 3a). These subunits presented the lowest difference between maximum and minimum fAPAR. A spring peak of fAPAR was evident in the three subunits. The Rolling Pampa and both Inland Pampas presented a higher intra-annual variability and a well-defined summer peak (Fig. 3b). The southernmost subunits (Flooding Pampa and Austral Pampa) were highly variable throughout the year and presented two clear peaks of fAPAR (Fig. 3c).

The dynamics of PAR, with a clear peak in December, determine that the two peaks of some of the subunits disappear when APAR is calculated (Fig. 3d, e, f). Except for the Rolling and Inland Pampas, with a peak of APAR in December, maximum radiation absorption occurs in November. Radiation use efficiency (ca) varied across precipitation gradients (Paruelo et al. 1997) and throughout the season (Piñeiro et al. 2006a). Empirical estimates of $\varepsilon a$ showed that in the RPG this coefficient presented minima in summer and maxima in winter (Fig. 4). The seasonal dynamics of $\varepsilon a$ determined a reduction in the contrast of ANPP throughout the year (Fig. 3g, h, i). The ratio between maximum and minimum APAR ranged between 5.45 and 3.12 and between 4.12 and 2.47 for ANPP.

Average ANPP for the period studied ranged from $5200 \mathrm{~kg}$ $\mathrm{DM} \cdot \mathrm{ha}^{-1} \cdot \mathrm{yr}^{-1}$ (West Inland Pampa) to $7860 \mathrm{~kg} \mathrm{DM}$. $\mathrm{ha}^{-1} \cdot \mathrm{yr}^{-1}$ (Northern Campos; Table 2; $260 \mathrm{~g} \mathrm{C} \cdot \mathrm{m}^{-2}$. $\mathrm{yr}^{-1}$ and $293 \mathrm{~g} \mathrm{C} \cdot \mathrm{m}^{-2} \cdot \mathrm{yr}^{-1}$, respectively). Estimates based on remotely sensed data produced figures within the range of values observed in field studies (Table 1). However, the variability observed during the period studied was, in general, lower than for biomass-based data: the range of ANPP (maximum-minimum values) varied between 11\% and 65\% of the mean value of the site (Table 2). The lower interannual variability may result from several factors. Remote sensing estimates considered a larger area to generate the estimate (a 

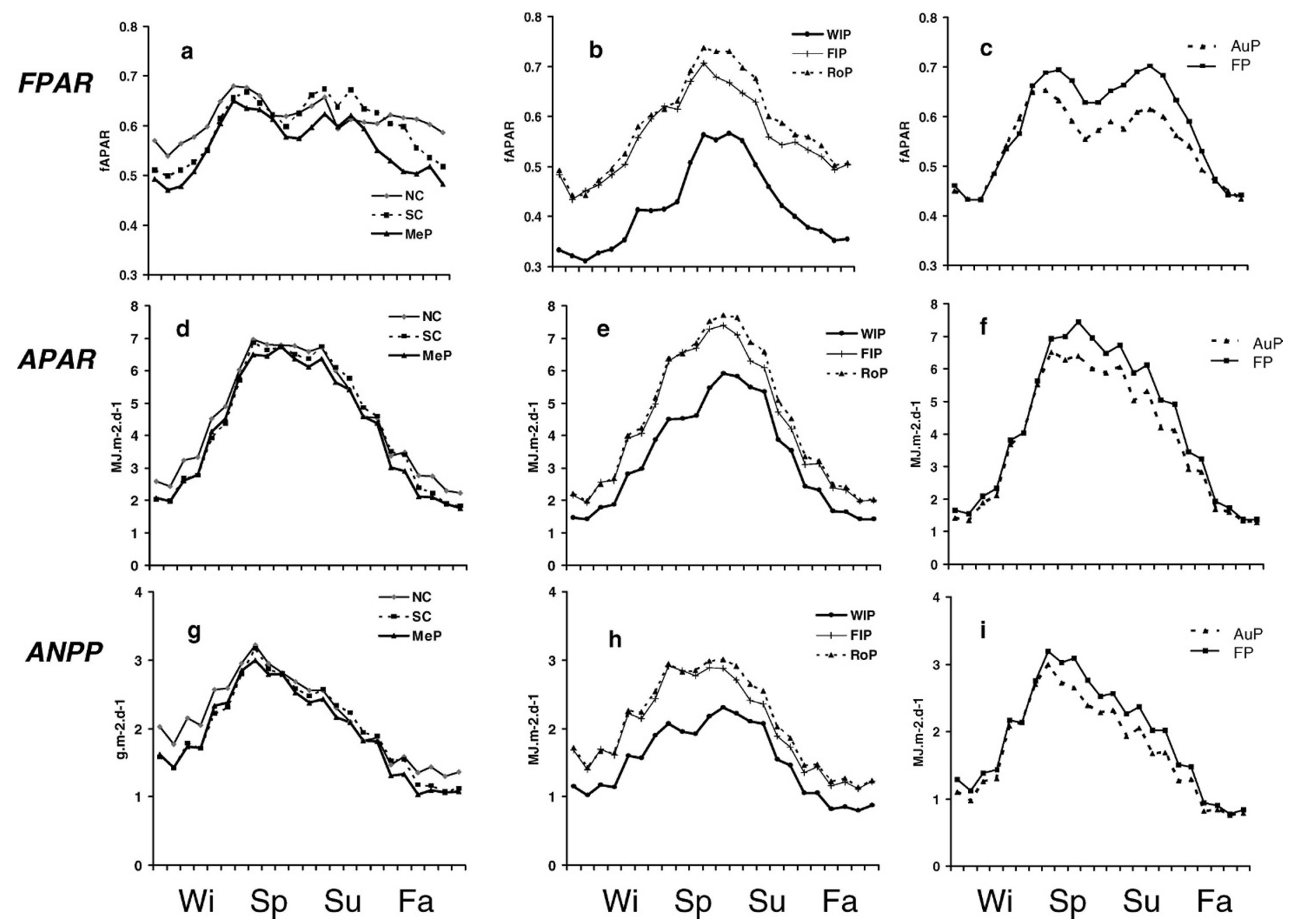

Figure 3. Average seasonal (Wi, winter; Sp, spring; Su, summer; Fa, fall) dynamics of the fraction of Photosynthetic Active Radiation (PAR) absorbed by the green canopy (FPAR; $\mathbf{a}, \mathbf{b}, \mathbf{c})$, amount of PAR absorbed by green tissues (APAR; $\mathbf{d}, \mathbf{e}, \mathbf{f}$ ), and aboveground net primary production (ANPP; $\mathbf{g}, \mathbf{h}, \mathbf{i})$ for the different phytogeographic units: NC, Northern Campos; SC, Southern Campos; FP, Flooding Pampa; RoP, Rolling Pampa; AuP, Austral Pampa; MeP, Mesopotamic Pampa; WIP, Western Inland Pampa; and FIP, Flat Inland Pampa. For each phytogeographic unit, 25 polygons corresponding to rangelands were selected. Each polygon was superimposed on temporal series of Enhanced Vegetation Index images provided by MODIS sensor (scenes h12v12 y h13v12) for the 2000-2006 period. Each polygon included 12-14 MODIS pixels.

$250 \times 250 \mathrm{~m}$ pixel), and, additionally, the area was always the same. Field estimates are pulling together temporal and spatial variability because samples of different dates correspond to distinct plots. Additionally, the use of a single model of RUE seasonal variation for the different units may have not reflected regional variation of those seasonal controls.

Although NDVI has been directly related to ANPP in many ecosystems (Tucker et al. 1985; Box et al.1989; Prince 1991; Paruelo et al. 1997, 2000), it is widely accepted now as an estimator of the fraction of photosynthetically active radiation absorbed by green vegetation (fAPAR). The different platforms provide data with different spatial and temporal resolution and extension.

The relationship between NDVI and fAPAR gave enormous importance to Monteith's model because now it is possible to estimate APAR from remotely sensed data and simple measures of PAR from a meteorological station. Monteith's model has been implemented in several biogeochemical models (i.e., CASA; Potter et al. 1993) and in monitoring programs of
ANPP worldwide (Running et al. 2000). The possibility of deriving estimates of APAR from remotely sensed data represented a crucial advance, particularly in rangeland ecology given the importance of the temporal and spatial variation of ANPP in range management. However, some uncertainties still remain. One of them is associated with the relationship between fAPAR and NDVI and the other to the estimates of coefficient of conversion of radiation into biomass, $\varepsilon$. Some authors suggest a nonlinear relationship between NDVI and fAPAR (Sellers et al. 1992), whereas the findings of others support a linear relationship (Choudhury 1987; Ruimy et al. 1994). The coefficient $\varepsilon$ is widely variable among biomes, and the available estimates have been derived, in general, from experiments performed at detailed scales and under controlled conditions or from modeling approaches (Field et al. 1995). Moreover, it has been shown that $\varepsilon$ varied with water availability and temperature (Prince 1991; Field et al. 1995; Nouvellon et al. 2000). Piñeiro et al. (2006a) showed for the RPG that seasonal patterns of $\varepsilon$ can be described from monthly 


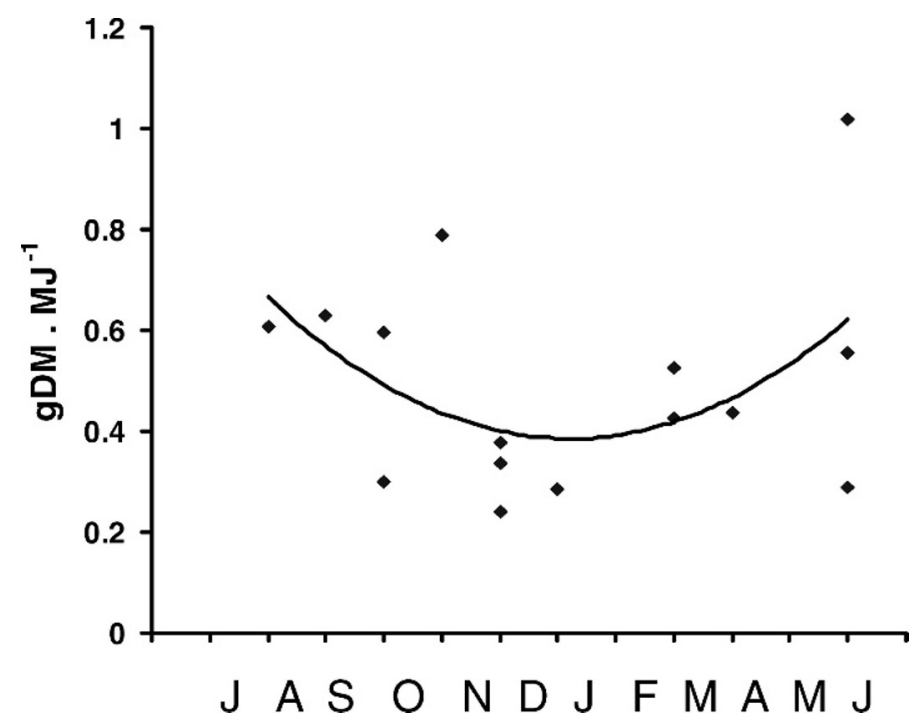

Figure 4. Observed values of radiation use efficiency $\left(\mathrm{g} \mathrm{DM} \cdot \mathrm{g} \mathrm{C}^{-1}\right.$ ) (points) for rangelands of the RPG (data from Piñeiro et al. 2006a). The model fitted was used to estimate ANPP from the Monteith model in Figure 3 and Table 2.

precipitation and temperature. This analysis also showed that ANPP estimates were more sensitive to $\varepsilon$ variations than to the differences among the specific methods used to estimate fAPAR-NDVI. Based on the findings of Gamon et al. (1992), recent studies showed that $\varepsilon a$ can be estimated remotely using a spectral index calculated from the reflectance in $530 \mathrm{~nm}$ and $570 \mathrm{~nm}$ (Photochemical Reflectance Index; Drolet et al. 2005; Inoue and Peñuelas 2006; Grace et al. 2007).

C Fluxes and Stocks: Simulation Analyses. Total C of rangelands ranged from $5004 \mathrm{~g} \mathrm{C} \cdot \mathrm{m}^{-2}$ to $15008 \mathrm{~g} \mathrm{C} \cdot \mathrm{m}^{-2}$ (Fig. 5a). An average $13 \%$ of such $\mathrm{C}$ corresponded to plant

Table 2. Average aboveground net primary production (ANPP) estimates and coefficient of variation (CV) and range of ANPP values over the mean values ( $n=6$ growing season) for each of the subunit of the Río de la Plata Grasslands (RPG). ${ }^{1}$ For each phytogeographic unit 25 polygons corresponding to rangelands were selected. Each polygon was superimposed on temporal series of Enhanced Vegetation Index images provided by MODIS sensor (scenes h12v12 y h13v12) for the 20002006 period. Each of the polygons included 12-14 MODIS pixels. ANPP was estimated using the Monteith (1972) model.

\begin{tabular}{cccc}
\hline RPG subunit & ANPP $\mathrm{g} \cdot \mathrm{m}^{-2} \cdot \mathrm{yr}^{-1}$ & CV & Range / mean \\
\hline NC & 786 & 7.4 & 0.18 \\
CS & 734 & 6.7 & 0.19 \\
MeP & 711 & 4.3 & 0.12 \\
AuP & 635 & 6.8 & 0.17 \\
FP & 707 & 4.5 & 0.13 \\
WIP & 553 & 24.1 & 0.65 \\
FIP & 732 & 9.7 & 0.25 \\
RoP & 760 & 3.8 & 0.11 \\
\hline
\end{tabular}

${ }^{1}$ NC indicates Northern campos; SC, Southern Campos; FP, Flooding Pampa; RoP, Rolling Pampa; AuP, Austral Pampa; MeP, Mesopotamic Pampa; WIP, Western Inland Pampa; and FIP, Flat Inland Pampa.
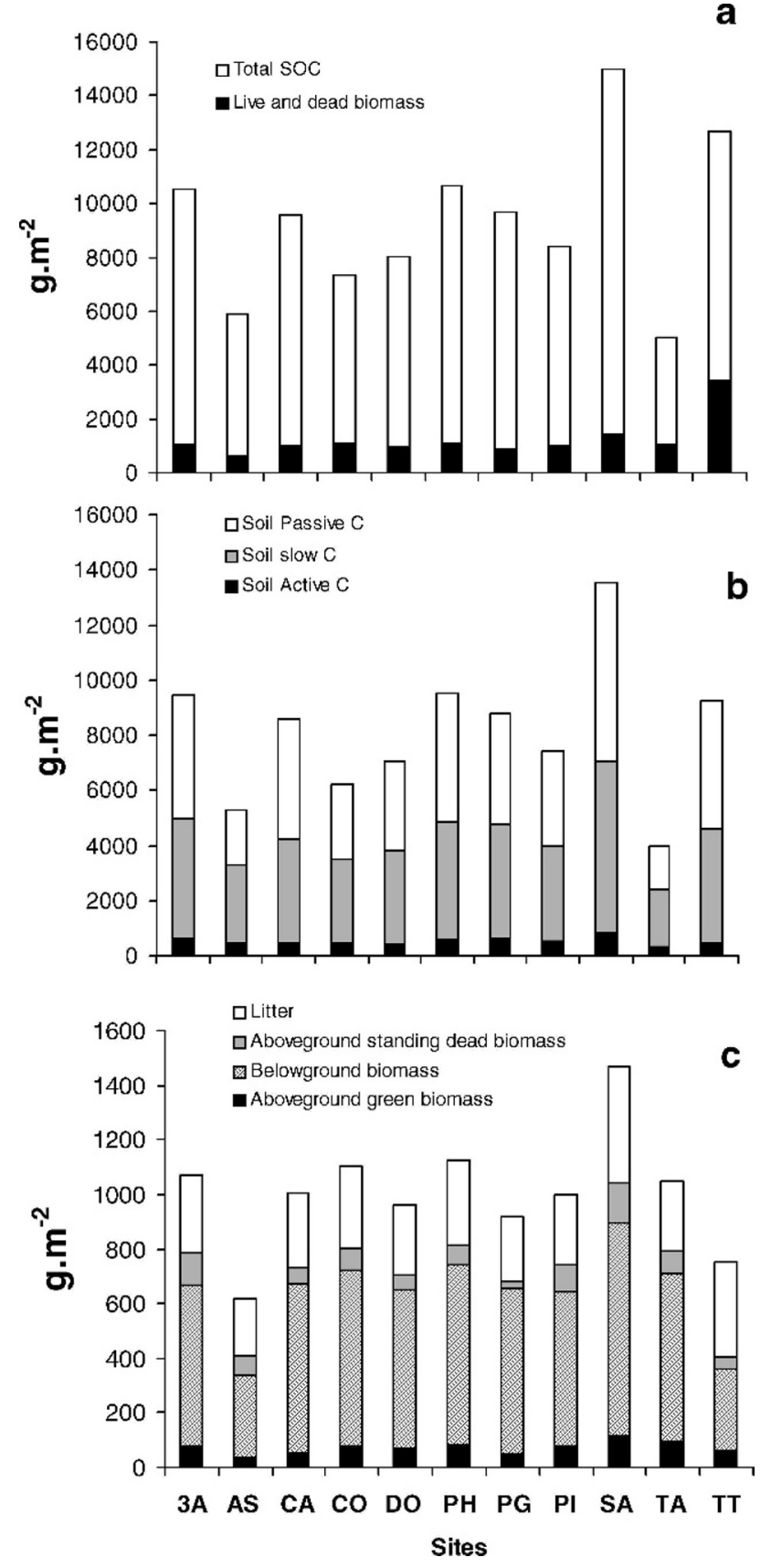

Figure 5. Carbon stocks as estimated by the Century model for 11 sites in the Río de la Plata Grasslands (see Fig. 1): total soil organic carbon and live + dead biomass (a), stocks of the three fractions of the soil organic C (b), and of litter, belowground biomass, and aboveground biomass (green and standing dead; c).

biomass (live + dead). The contribution of plant biomass varied from $9.5 \%$ to $27 \%$ among sites. The largest plant C stock corresponded to belowground biomass (Fig. 5b). Aboveground green biomass represented, on average, less than $7 \%$ of plant $\mathrm{C}$. Litter and standing dead material accounted for $33 \%$ of $\mathrm{C}$ in the biomass. SOC was concentrated in the slow and passive compartments of the organic matter. Active soil pool represented only $6.7 \%$ of the SOC.

As field data showed (see above), BNPP was, on average, $14 \%$ higher than ANPP. NPP varied among sites between 

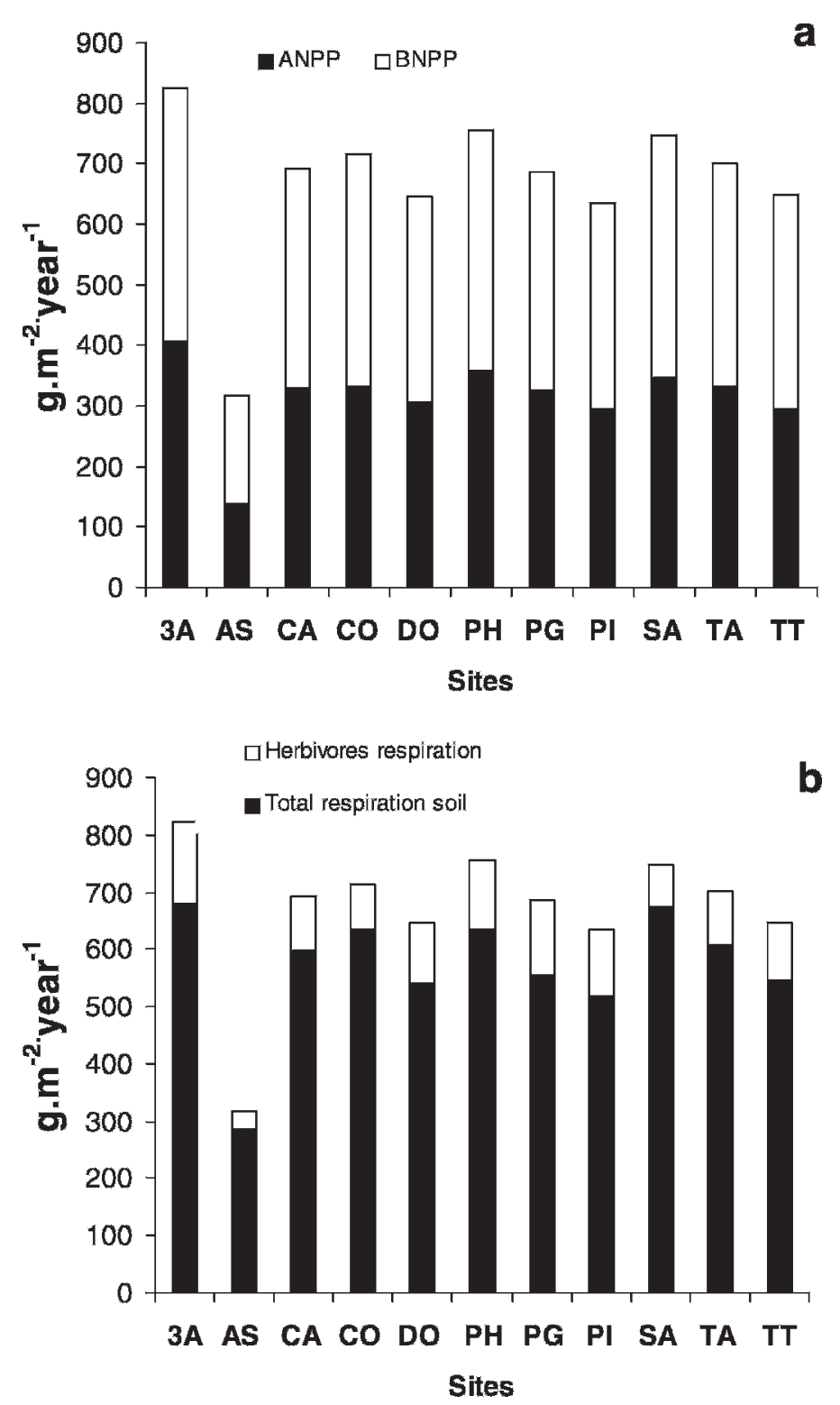

Figure 6. Carbon fluxes estimated by the Century model for 11 sites in the Río de la Plata Grasslands (see Fig. 1): Aboveground (ANPP) and belowground (BNPP) net primary production (a) and herbivore and total soil respiration $(\mathbf{b})$.

$316 \mathrm{~g} \mathrm{C} \cdot \mathrm{m}^{-2} \cdot \mathrm{yr}^{-1}$ and $825 \mathrm{~g} \mathrm{C} \cdot \mathrm{m}^{-2} \cdot \mathrm{yr}^{-1}$ (Fig. 6a). ANPP simulated by the Century model presented a range $(138-406 \mathrm{~g}$ $\left.\mathrm{C} \cdot \mathrm{m}^{-2} \cdot \mathrm{yr}^{-1}\right)$ slightly narrower than the estimates derived from field data $\left(95-439 \mathrm{~g} \mathrm{C} \cdot \mathrm{m}^{-2} \cdot \mathrm{yr}^{-1}\right)$ and wider than those derived from MODIS data $\left(234-353 \mathrm{~g} \mathrm{C} \cdot \mathrm{m}^{-2} \cdot \mathrm{yr}^{-1}\right)$. Most of the $\mathrm{C}$ of the system was released as soil respiration (litter, dead roots, and soil organic matter respiration; Fig. 6b). Herbivore respiration (considering domestic grazers) accounted for $23 \%$ of C losses (Fig. 6b).

C Stocks: Field Data Estimates. In an analysis based on 16 native grassland sites, Altesor et al. (2006) and Piñeiro et al. (2009) characterized the belowground C pools: root biomass, particulate organic matter (POM), and mineral-associated organic matter (MAOM). POM would correspond roughly to the more labile fraction of soil carbon and MAOM to the slow
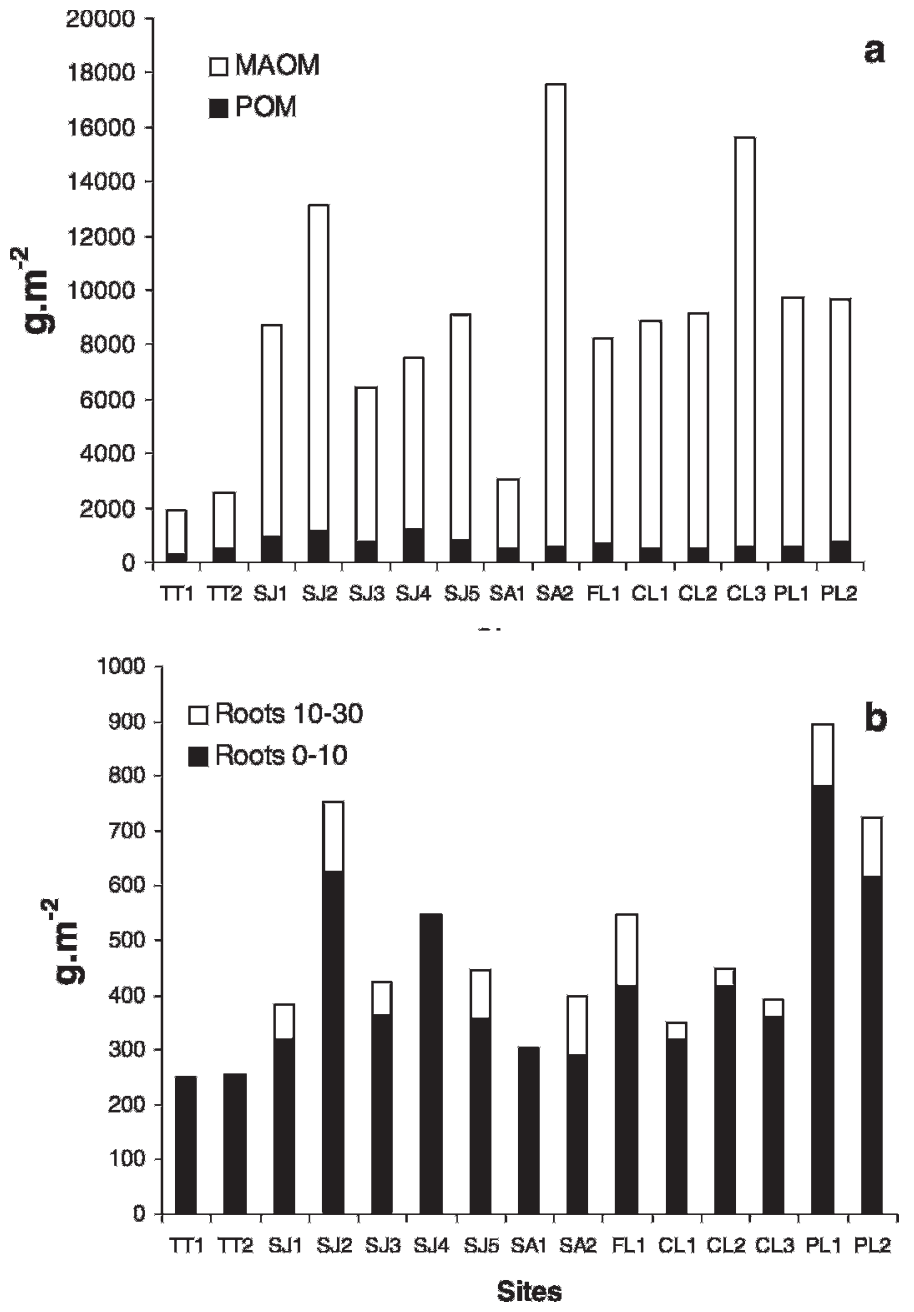

Figure 7. Carbon stocks estimated from field surveys (see Altesor et al. 2006 for details on the sites): mineral-associated organic matter (MAOM) and particulated organic matter (POM; a) and carbon in root biomass at two depths (b).

and passive $\mathrm{C}$ pools. The amount of SOC in the first meter of the soil varied between $1893 \mathrm{~g} \mathrm{C} \cdot \mathrm{m}^{-2}$ and $17577 \mathrm{~g} \mathrm{C} \cdot \mathrm{m}^{-2}$ depending on the site (average $=8748 \mathrm{~g} \mathrm{C} \cdot \mathrm{m}^{-2}$; Fig. 7a). The sites with the lowest SOC content were located on shallow soils (less than $20 \mathrm{~cm}$ deep). On average $10 \%$ of total SOC corresponded to the POM fraction.

Root biomass data were available only for the first $30 \mathrm{~cm}$ of soil profile. The $\mathrm{C}$ accumulated in belowground organs varied between $248 \mathrm{~g} \mathrm{C} \cdot \mathrm{m}^{-2}$ and $894 \mathrm{~g} \mathrm{C} \cdot \mathrm{m}^{-2}$ (average $=474 \mathrm{~g}$ $\mathrm{C} \cdot \mathrm{m}^{-2}$; Fig. $7 \mathrm{~b}$ ). For the sites studied, $6.6 \%$ of the soil $\mathrm{C}$ was located in the roots. As expected a large fraction of the root biomass was concentrated in the first $10 \mathrm{~cm}(84 \%$ or $88 \%$ considering shallow soils).

\section{Environmental Controls of C Stocks and Fluxes}

Climatic factors have been identified as the major controls of key $\mathrm{C}$ fluxes in grasslands. Gradient analysis provided useful insights into the determinants of $\mathrm{C}$ dynamics in rangelands. Probably the best documented and studied relationship is the positive and linear correlation between ANPP and MAP (Lauenroth 1979; Sala et al. 1988). Under relatively constant 


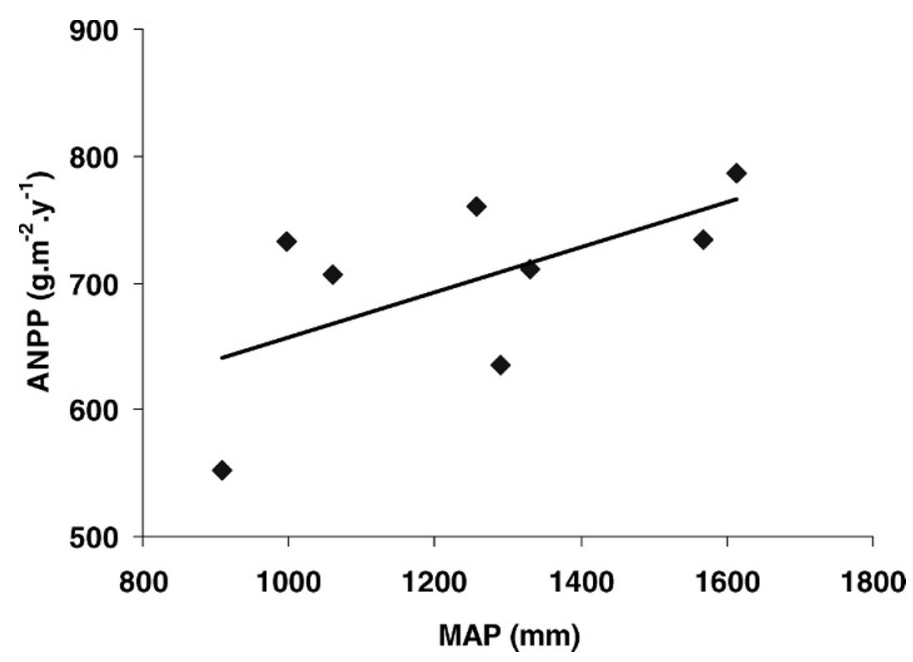

Figure 8. Relationship between the average aboveground net primary production (ANPP; $\mathrm{g} \mathrm{DM} \cdot \mathrm{m}^{-2} \cdot \mathrm{yr}^{-1}$ ) and mean annual precipitation (MAP; $\left.\mathrm{mm} \cdot \mathrm{yr}^{-1}\right)$ of a representative weather station of the phytogeographic subunit. The line represents the regression model fitted (ANPP $\left.=475+0.179 \mathrm{MAP}, r^{2}=0.37, P<0.05\right)$. ANPP was estimated from remotely sensed data using Monteith (1972) models. The weather stations used were Ezeiza (Rolling Pampa), Dolores (Flooding Pampa), Salto (Northern Campos), Treinta y Tres (Southern Campos), Mar del Plata (Austral Pampa), Gualeguaychú (Mesopotamic Pampa), Rio Cuarto (Western Inland Pampa), and Marcos Juárez (Flat Inland Pampa).

precipitation, ANPP showed also a positive relationship with temperature (Epstein et al. 1997). Carbon stocks in grasslands are largely determined by abiotic factors too (Burke et al. 1989); they increase with precipitation mainly as a result of increased primary production (input) and decrease with increasing temperature as a result of increased decomposition (output; McDaniel and Munn 1985). Soil characteristics play a critical role in determining $\mathrm{C}$ stocks and fluxes at the landscape scale, though their influence is, in general, less important than climatic factors at the regional scale. Sala et al. (1988) and Epstein et al. (1997) showed that soil texture, through its effects on water holding capacity, is a major control of $\mathrm{C}$ gains. Silt and clay content increase the carbon content of rangeland soils (Burke et al. 1989). Inertia or "system memory" effects have been identified as a major determinant of interannual changes of C gains (Oesterheld et al. 2001; Wiegand et al. 2004).

How well do the ANPP data compiled for the RPG fit these general patterns? For field ANPP data, differences were not associated with geographical or climatic gradients. Several reasons may contribute to this. On the one hand, most of the available studies corresponded to the more humid portion of the RPG restricting the range of the data. Management and edaphic factors (not always recorded) seem to be the major controls of the spatial variability in ANPP in this dataset: the highest values of ANPP were associated with deep soil and with the introduction of cultivated species (generally associated with fertilization practices). On the other hand, ANPP was estimated using several approaches, and this introduces an additional source of variation that may mask general patterns.

ANPP estimates based on remotely sensed data were derived using the same protocol over the region and correspond to a spatial (many polygons) and temporal (six growing seasons) mean. Average ANPP showed a linear relationship with the MAP of a representative weather station of the subunit (Fig. 8). The average precipitation use efficiency (ANPP/MAP) was similar to those reported in the literature $\left(0.56 \mathrm{~g} \cdot \mathrm{m}^{-2} \cdot \mathrm{mm}^{-2}\right)$. However, the Precipitation Marginal Response (PMR; the slope of the relationship ANPP - MAP; Verón et al. 2005) was lower $\left(0.17 \mathrm{~g} \cdot \mathrm{m}^{-2} \cdot \mathrm{mm}^{-1}\right)$ than the values reported for studies that covered a broader precipitation gradient $(0.48-$ $0.6 \mathrm{~g} \cdot \mathrm{m}^{-2} \cdot \mathrm{mm}^{-1}$; Sala et al. 1988; McNaughton et al. 1993; Paruelo et al. 1999). The proportion of the ANPP variability accounted for by MAP was $0.37\left(r^{2}\right.$, Fig. 8), again a lower value than in the cited studies. Restricting the analysis to a portion of the precipitation gradient typical of grassland areas and dealing with the wettest part of the gradient should explain the lower PMR and $r^{2}$ observed. Edaphic factors (soil depth, texture, nutrient availability) and management issues (grazing regimes, stock density) should be considered to account for the unexplained variance (Paruelo et al. 1999; Altesor et al. 2005; Piñeiro et al. 2006b).

Edaphic and climatic factors were associated with the regional variation of the SOC (POM+MAOM) recorded in the field (Table 3). SOC was negatively associated with gravel and sand content and positively related with MAP and root biomass. Edaphic factors showed a higher correlation with SOC than climate variables. The same pattern emerged from the simulated SOC data. Total SOC and every soil fraction showed a negative relationship with sand content (data not shown).

\section{Disturbance Effects on C Dynamics in the RPG}

Among the many types of disturbance that may affect $\mathrm{C}$ fluxes and stocks, grazing by domestic herbivores, agricultural practices, and fire have an overwhelming importance in grassland areas (Oesterheld et al. 1999). Grazing may either increase or decrease ANPP. Rusch and Oesterheld (1997) found in the Flooding Pampa that ungrazed areas showed higher ANPP than grazed plots, even if the initial biomass was the same. Altesor et al. (2005), working in the Southern Campos, found that grazed areas produced $51 \%$ more than the ungrazed paired situation. However, when the initial biomass was the same, ungrazed areas were $29 \%$ more productive. Such differences may be associated with the effects of the structural changes promoted by grazing (species and plant functional type composition or biomass vertical distribution) on the resource level (water, nutrients, and light). Grazing, by removing or

Table 3. Beta coefficient, coefficient of determination $\left(r^{2}\right)$, Student's $t$, and probability level for the independent variables included in a multiple regression forward stepwise model for Soil Organic Carbon $(\mathrm{SOC}=$ particulated organic matter + mineral-associated organic matter). $N=15$.

\begin{tabular}{lrrrr}
\hline \multicolumn{1}{c}{ Variable } & \multicolumn{1}{c}{ Beta } & $r^{2}$ & \multicolumn{1}{c}{$t$} & $P$-value \\
\hline Gravel content \% & -0.747 & 0.636 & -3.568 & 0.006 \\
Sand content \% & -0.756 & 0.690 & -3.336 & 0.009 \\
Mean annual precipitation & 0.481 & 0.738 & 1.950 & 0.083 \\
Root biomass & 0.758 & 0.824 & 2.518 & 0.033 \\
\hline
\end{tabular}


avoiding the accumulation of senescent material, may increase radiation interception. As long as light was the limiting factor, grazing would increase ANPP.

Altesor et al. (2006) analyzed the effect of grazing regime on $\mathrm{C}$ stocks in a network of grazed sites and herbivore exclusions located in the Southern Campos. Although no changes were detected in total soil $\mathrm{C}$ among grazing treatments, a differential effect on the labile and recalcitrant fraction of the soil organic matter was evident. Soil carbon was higher under grazing in the upper layer, probably because of the higher biomass of belowground organs. The pattern changed with depth: C stocks were higher in ungrazed sites because of an increase in the more recalcitrant organic matter pool. At least in the short term, the dynamics of SOC seems to be influenced in a complex way by changes in $\mathrm{C}$ inputs and vertical distribution, in $\mathrm{N}$ availability, and in plant functional types composition. In the long term (decades or centuries), grazing effects seems to differ. Modeling studies with Century (Piñeiro et al. 2006b) suggested a reduction in $\mathrm{C}$ stocks mainly to higher $\mathrm{N}$ outputs that opened the $\mathrm{N}$ cycle and constrained $\mathrm{C}$ accumulation in soils, reducing SOC by $22 \%$.

Crop expansion in the RPG had a significant effect on the seasonality of carbon gains and almost no effect on total amount fixed (Guerschman et al. 2003). As a matter of fact, Guerschman (2005) estimated that the NPP of agricultural systems was $15 \%$ lower than of the native grasslands. Agriculture basically modifies the shape of the seasonal curve of primary production but not the area underneath. An increase in croplands also reduced the interannual variability of the seasonal patterns of carbon gains (Guerschman and Paruelo 2005). The introduction of double cropping systems during the last two decades (wheatsoybean) generated a double peak in the seasonal curve of ANPP and an increase in C gains (Guerschman and Paruelo 2005). Guerschman (2005) estimated that the human appropriation of NPP in the Argentine portion of the RPG varied between 19\% and $45 \%$. The average was substantially higher than the average appropriation estimated by Vitousek et al. (1997) for the whole planet $(15.2 \%)$.

Tree plantations (mainly Pinus and Eucalyptus species) have the potential of increasing C gains. Jobbágy et al. (2006) showed, based on a remote sensing analysis, that afforestation in the Mesopotamic Pampa and in the Uruguayan Campos intercepted $22 \%$ more radiation than the rangelands that they replaced. Field-based estimates of ANPP showed the same pattern (Jobbágy et al. 2006).

Large quantities of $\mathrm{C}$ sequestered in grassland soils are transferred into the atmosphere when grasslands are ploughed and converted into annual or perennial crops (Davidson and Ackerman 1993). Tillage increases soil organic matter decomposition and decreases carbon stocks mainly as a result of breaking up soil aggregates and exposing residues to decomposers (Elliot 1986). Burke et al. (1989) estimated, for the Central Plains of the United States, C losses of $40 \%$ of the original values because of cultivation. C stocks after plowing decreased significantly and very rapidly (Cole et al. 1989), but after $50 \mathrm{yr}$ of abandonment stocks had not yet reached the levels of native soils (Burke et al. 1995; Ihori et al. 1995). Álvarez et al. (1998), Andriulo et al. (1999), and Álvarez (2001) documented the C losses due to annual croplands for the
RPG. Preliminary data suggest that afforestation also increases C losses (Carrasco-Letelier et al. 2004).

The agricultural transformation of grasslands also affects the dynamics of other trace gases such as methane and nitrous oxide. Field experiments comparing native grasslands and adjacent cultivated plots have shown that cultivation decreases the uptake of methane and increases the emissions of nitrous oxide, contributing to the increasing concentrations of these gases in the atmosphere (Mosier et al. 1991). No data on methane uptake or $\mathrm{N}$ oxide production are available for the RPG.

Fire is another potential disturbance in the humid grasslands. In a meta-analysis, Oesterheld et al. (1999) showed that fire tended to increase ANPP in subhumid and humid grasslands. In the RPG fire is now restricted to the Campos subdivisions and small patches in the Mesopotamic Pampa and the Flooding Pampa. Fires are usually started by ranchers to eliminate lowquality forage and favor the regrowth of a more palatable and nutritious biomass. Agricultural use significantly reduced fire frequency in the RPG (Di Bella et al. 2006). Piñeiro et al. (2006b), based on simulation analyses, showed that fire frequencies and intensities interact with the grazing regime determining long-term $\mathrm{C}$ dynamics and stocks.

\section{MANAGEMENT IMPLICATIONS}

Figure 9 presents a general synthesis of the available information on $\mathrm{C}$ stocks and fluxes for the RPG. Most fluxes and stocks were derived from remote sensing and modeling, and just a few from field data. Modeling has been an important source of information to derive a general $\mathrm{C}$ balance for the RPG. We have only a partial and incomplete understanding of $\mathrm{C}$ dynamics and stocks in grasslands; many uncertainties and caveats still remain. There is, on the one hand, a lack of a network of field estimates of ANPP and BNPP able to capture the temporal and spatial heterogeneity of $\mathrm{C}$ gains using a common measurement protocol. Remotely sensed techniques based on Monteiths model and on MODIS data have the potential to generate a coherent and spatially explicit database on ANPP. However, more work is needed to improve estimates of the spatial and temporal (intra- and interannual) variability of RUE. The absence of a flux tower network restricts the ability to track seasonal changes in $\mathrm{C}$ uptake and to understand fine-scale controls of $\mathrm{C}$ dynamics.

The applied importance of a better understanding of $\mathrm{C}$ fluxes and stocks in the RPG derives from at least two issues: first, the possibility of improving ANPP estimates for rangeland management objectives, and second, the design of systems able to simultaneously sequester $\mathrm{C}$ and maintain the integrity of the native ecosystems. ANPP is the major determinant of stock density in the extensive grazing systems of the RPG (Oesterheld et al. 1998). A proper characterization of the temporal and spatial variability became a critical element in rangeland management. Remote sensing estimates of ANPP have been proposed as the basis of monitoring and warning systems for extensive ranches (Grigera et al. 2007).

Grassland areas have a potential to reduce greenhouse gas emissions and even sequester C. Piñeiro et al. (this issue) showed that the potential of $\mathrm{C}$ sequestration is tightly linked to $\mathrm{N}$ dynamics. Management actions directed to reduce $\mathrm{N}$ losses 


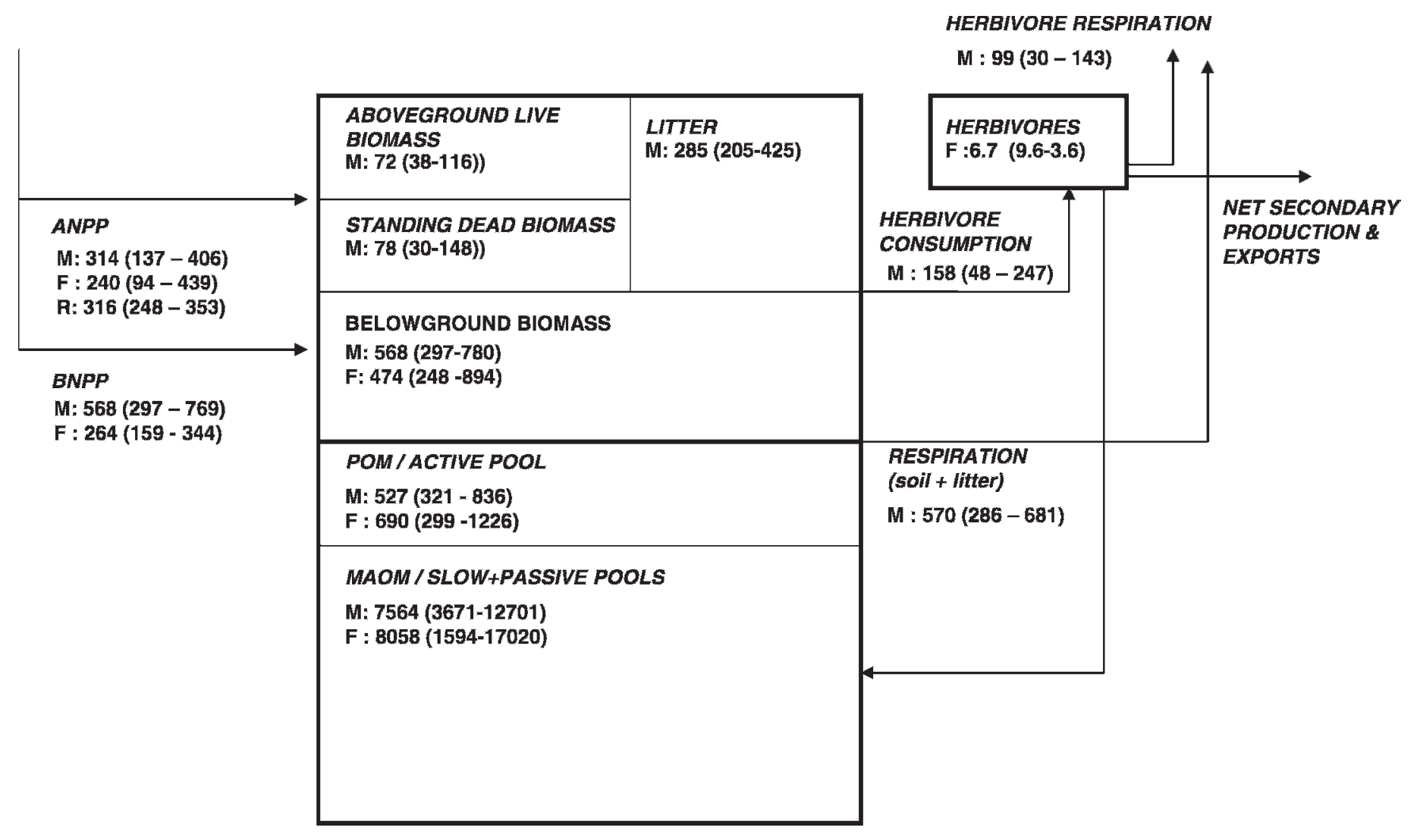

Figure 9. Carbon balance for the Río de la Plata rangelands. Estimates based on modeling (M), field studies (F), and remote sensing techniques (R) are presented. The values are expressed in $\mathrm{g} \mathrm{C} \cdot \mathrm{m}^{-2}$ (stocks) and $\mathrm{g} \mathrm{C} \cdot \mathrm{m}^{-2} \cdot \mathrm{yr}^{-1}$ (fluxes). Values in parentheses corresponded to the range of observed/simulated values. Abbreviations: ANPP, aboveground net primary production; BNPP, belowground net primary production; POM, particulated organic matter; and MAOM, mineral-associated organic matter.

or to increase $\mathrm{N}$ inputs may increase $\mathrm{C}$ accumulation in highly recalcitrant pools. Such alternatives, not yet studied in depth, include different grazing rotational schemes, fertilization, and legume introduction, among others.

The RPGs are experiencing a particular land cover change, the conversion of native grasslands to tree plantations. Afforestation of grasslands will probably be reinforced by the prospective carbon sequestration market. Federal laws promoting afforestation with fast-growing tree species expanded tree plantations over vast areas of the RPG. The processes, originally attached to national investment and often integrated with local industrial processing (Jobbágy et al. 2005), are now driven by multinational companies that channel most of the production overseas. Highly productive grasslands in which crop production was usually not feasible (rocky or sandy soils, steep slopes, etc.) hosted most of these plantations (Jobbágy et al. 2005). C sequestration is often presented as one of the potential benefits of afforestation. However, it is not clear that the higher ANPP of tree plantations with respect to rangeland areas would result in higher $\mathrm{C}$ accumulation and storage in the system. Regarding the soil component, local evidence (Jobbágy and Jackson 2003; Delgado et al. 2006) and a global synthesis (Paul et al. 2002) showed that grassland soils would not increase $\mathrm{C}$ contents once forested and that in the more humid systems (Northern and Southern Campos) soils may lose C (Jackson et al. 2002; Kirschbaum et al. 2008). An analysis of the potential of afforestation of grassland areas for $\mathrm{C}$ sequestration must take into account the residence time of $\mathrm{C}$ in the ecosystem. Moreover, it would be important to consider the stability of the $\mathrm{C}$ storage pools (aboveground biomass vs. soil organic matter). Afforestation, on the other hand, had a large impact on different ecological dimensions. Soils under eucalyptus plantations acidified most likely because of high rates of calcium cycling following tree establishment (Jobbágy and Jackson 2003). In addition, the establishment of tree plantations had striking effects on evapotranspiration, increasing it up to $80 \%$ (Nosetto et al. 2005). Depending on the hydraulic properties of the soils and aquifers, tree plantation can also affect groundwater hydrology and salt dynamics, resulting in groundwater consumption of up to $300 \mathrm{~mm} \cdot \mathrm{yr}^{-1}$ and large accumulations of salts in soils and aquifers (Jobbágy and Jackson 2004; Nosetto et al. 2005).

\section{LITERATURE CITED}

Altesor, A. I., M. Oesterheld, E. Leoni, F. Lezama, and C. Rodríguez. 2005. Effect of grazing on community structure and productivity of a Uruguayan grassland. Plant Ecology 179:83-91.

Altesor, A. I., G. Piñeiro, F. Lezama, R. D. Jackson, M. Sarasola, and J. M. Paruelo. 2006. Ecosystem changes associated with grazing removal in sub-humid grasslands of South America. Journal of Vegetation Science 17:323-332.

Álvarez, R. 2001. Estimation of carbon losses by cultivation from soils of the Argentine Pampa using the Century model. Soil Use and Management 17:62-66. 
Álvarez, R., M. E. Russo, P. Prystupa, J. D. Scheiner, and L. Blotta. 1998. Soil carbon pools under conventional and no-tillage systems in the Argentine Rolling Pampa. Agronomy Journal 90:138-143.

Andriulo, A., J. Guerif, and B. Mary. 1999. Evolution of soil carbon with various cropping sequences on the rolling pampas. Determination of carbon origin using variations in natural $13 \mathrm{C}$ abundances. Agronomie 19:349364.

Asrar, G., M. Fuchs, E. T. Kanemasu, and J. L. Hatfield. 1984. Estimating absorbed photosynthetic radiation and leaf area index from spectral reflectance in wheat. Agronomy Journal 76:300-306.

BALDI, G. 2007. Cambios en la estructura del paisaje en la región de los Pastizales del Río de la Plata (período 1985-2005) [thesis]. Buenos Aires, Argentina: Universidad de Buenos Aires, Facultad de Agronomía. 89 p.

Baldi, G., J. P. Guerschman, and J. M. Paruelo. 2006. Characterizing fragmentation in temperate South America grasslands. Agriculture, Ecosystems \& Environment 116:197-208.

Baldi, G., and J. M. Paruelo. 2008. Land use and land cover dynamics in South American temperate grasslands. Ecology and Society 13(2):6.

Bemhaja, M., and F. Olmos. 1996. Producción de pasturas en suelos arenosos. Montevideo, Uruguay, Serie Técnica INIA 80. 78 p.

Bermúdez, R., and W. Ayala. 2005. Producción de forraje de un campo natural de la zona de lomadas del este. Montevideo, Uruguay. Serie Técnica INIA 151. 78 p.

Berreta, E. J., and M. Bemhaja. 1998. Producción estacional de comunidades naturales sobre suelos de basalto de la unidad Queguay Chico. Montevideo, Uruguay. Serie Técnica INIA 102. 78 p.

Box, E. O., B. N. Holben, and V. Kalb. 1989. Accuracy of the AVHRR vegetation index as a predictor of biomass, primary productivity and net CO2 flux. Vegetatio 80:71-89.

Burke, I. C., W. K. Lauenroth, and D. P. Coffin. 1995. Soil organic matter recovery in semiarid grasslands: implications for the conservation reserve program. Ecological Applications 5:793-801.

Burke, I. C., C. M. Yomker, W. J. Parton, C. V. Cole, K. Flach, and D. S. Schimel. 1989. Texture, climate and cultivation effects on soil organic content in U.S. grassland soils. Soil Science Society of America Journal 53:800-805.

Carrasco-letelere, L., G. Eguren, C. Castineira, O. Parra, and D. Panario. 2004. Preliminary study of prairies forested with eucalyptus $\mathrm{sp}$. at the northwestern Uruguayan soils. Environmental Pollution 125:49-55.

ChoudhuRY, B. 1987. Relationships between vegetation indices, radiation absorption and net photosynthesis evaluated by a sensitivity analysis. Remote Sensing of Environment 22:209-233.

Cole, C. V., I. C. Burke, W. J. Parton, D. S. Schimel, and J. W. B. Stewart. 1989. Analysis of historical changes in soil fertility and organic matter levels of the North American Great Plains. In: P. W. Unger, T. V. Sneed, and R. W. Jensens [EDS.]. Proceedings of the International Conference on Dryland Farming. College Station, TX, USA: Texas A\&M University. p. 436-438.

Davidson, E. A., and I. L. Ackerman. 1993. Changes in soil carbon inventories following cultivation of previously untilled soils. Biogeochemistry 20:161-193.

Delgado, S., F. Alliaume, F. García Préchac, and J. Hernández. 2006. Efecto de las plantaciones de Eucalyptus sp. sobre el recurso suelo en Uruguay. Agrociencias 10:95-107.

Deregibus, V. A., M. Oesterheld, R. Boco, J. Aranguren, and M. Landi. 1985. Producción forrajera y de carne en pastizales naturales de la Provincia de Entre Ríos pastoreados en forma alternativa y planificada. Buenos Aires, Argentina: Asociación Argentina de Consorcios Regionales de Experimentacion Agricola. p. 63-70.

De Wysiecky, M. L., and C. Perez. 1994. Producción de raíces de dos pastizales pastoreados de la Sierras de la Ventana, Provincia de Buenos Aires, Argentina. Ecología Austral 4:95-99.

Dı Bella, C. M., E. G. Jobbágy, J. M. Paruelo, and S. Pinnock. 2006. Environmental and land use controls of fire density in South America. Global Ecology and Biogeography 15:192-199.

DoLL, U. M. 1991. C-14 translocation to the below ground subsystem in a temperate humid grassland (Argentina). In: B. L. McMichael and H. Persson [EDS.]. Plant roots and their environment. Amsterdam, the Netherlands: Elsevier Science Publishers. p. 350-358.
Drolet, G. G., K. F. Huemmrich, F. G. Hall, E. M. Middleton, T. A. Black, A. G. Barr, AND H. A. Margolis. 2005. A MODIS-derived photochemical reflectance index to detect inter-annual variations in the photosynthetic light-use efficiency of a boreal deciduous forest. Remote Sensing of Environment 98:212-224.

Durán, A. 1991. Los suelos del Uruguay. Montevideo, Uruguay: Hemisferio Sur. $398 \mathrm{p}$.

ECKBLAD, J. W. 1991. How many samples should be taken? Bioscience 41:346-348

EцLıт, E. T. 1986. Aggregate structure and carbon, nitrogen and phosphorus in native and cultivated soils. Soil Science Society of America Journal 50:627-632.

Epstein, H. E., W. K. Lauenroth, I. C. Burke, and D. P. Coffin. 1997. Regional productivity patterns of $\mathrm{C} 3$ and $\mathrm{C} 4$ functional types in the US Great Plains. Ecology 78:722-731.

Field, C. B., J. T. Randerson, and C. M. Malmstrom. 1995. Global net primary production: combining ecology and remote Sensing. Remote Sensing of Environment 51:74-88.

Formoso, D. 2001. Producción y valor nutritivo del campo natural y mejoramientos extensivos. In: Utilización y Manejo de Mejoramientos Extensivos con Ovinos. Montevideo, Uruguay: Secretariado Uruguayo de la Lana. p. 7-24.

Gamon, J. A., J. Penuelas, and C. B. Field. 1992. A narrow-waveband spectral index that tracks diurnal changes in photosynthetic efficiency. Remote Sensing of Environment 41:35-44

Gill, R. A., R. H. Kelly, W. J. Parton, K. A. Day, R. B. Jackson, J. A. Morgan, J. M. O. Scurlock, L. L. Tieszen, J. V. Castle, D. S. OJima, and X. S. Zhang. 2002. Using simple environmental variables to estimate below-ground productivity in grasslands. Global Ecology and Biogeography 11:79-86.

Grace, J., C. Nichol, M. Disney, P. Lewis, T. Qualfe, and P. Bowyer. 2007. Can we measure terrestrial photosynthesis from space directly, using spectral reflectance and fluorescence? Global Change Biology 13:1484-1497.

Grigera, G., M. Oesterheld, and F. Pacín. 2007. Monitoring forage production for farmers' decision making. Agricultural Systems 94:637-648.

Guerschman, J. P. 2005. Análisis regional de impacto de los cambios del uso de la tierra sobre el funcionamiento de los ecosistemas en la región pampeana (Argentina) [thesis]. Buenos Aires, Argentina: Universidad de Buenos Aires, Facultad de Agronomía. 172 p.

Guerschman, J. P., and J. M. Paruelo. 2005. Agricultural impacts on ecosystem functioning in temperate areas of North and South America. Global and Planetary Change 47:170-180.

Guerschman, J. P., J. M. Paruelo, and I. Burke. 2003. Land use impacts on the normalized difference vegetation index in temperate Argentina. Ecological Applications 13:616-628.

Hall, A. J., C. M. Rebella, C. M. Ghersa, and J.-P. Culot. 1992. Field crop systems of the Pampas. In: C. J. Pearson [ED.]. Field crop ecosystems. Amsterdam, the Netherlands: Elsevier. p. 413-450.

Hannah, L., J. L. Carr, and A. Lankerani. 1995. Human disturbance and natural habitat: a biome analysis of a global data set. Biodiversity and Conservation 4:128-155.

Hidalgo, L. G., and M. Caunépé. 1991. Producción de forraje de comunidades forrajeras de la Pampa Deprimida. Revista CREA 149:58-62.

Hijmans, R. J., S. E. Cameron, J. L. Parra, P. G. Jones, and A. Jarvis. 2005. Very high resolution interpolated climate surfaces for global land areas. International Journal of Climatology 25:1965-1978.

Huete, A., K. Didan, T. Miura, E. P. Rodriguez, X. Gao, and L. G. Ferreira. 2002. Overview of the radiometric and biophysical performance of the MODIS vegetation indices. Remote Sensing of Enviroment 83:195-213.

HuI, D., AND R. B. JaCKSON. 2006. Geographical and interannual variability in biomass partitioning in grassland ecosystems: a synthesis of field data. New Phytologist 169:85-93.

Ihori, T., I. C. Burke, W. K. Lauenroth, and D. P. Coffin. 1995. Effect of cultivation and abandonment on soil organic matter in northeastern Colorado. Soil Science Society of America Journal 59:1112-1119.

Inoue, Y., and J. Peñuelas. 2006. Relationship between light use efficiency and photochemical reflectance index in soybean leaves as affected by soil water content. International Journal of Remote Sensing 27:5109-5114. 
Instituto Nacional de Tecnología Agropecuaria. 1989. Mapa de suelos de la provincia de Buenos Aires-Escala 1:500.000. Buenos Aires, Argentina: Instituto Nacional de Tecnología Agropecuaria. $513 p$.

Jackson, R. B., J. L. Banner, E. G. Jobbágy, W. T. Pockman, and D. H. Wall. 2002. Ecosystem carbon loss with woody plant invasion of grasslands. Nature 418:623-626.

JobBÁGY, E. G., AND R. JaCKSON. 2000. The vertical distribution of soil organic carbon and its relation to climate and vegetation. Ecological Applications 10:423-436.

JobBáGy, E. G., AND R. JaCKSON. 2003. Patterns and mechanisms of soil acidification in the conversion of grasslands to forests. Biogeochemistry 54:205229.

JobbáGy, E. G., and R. JaCkson. 2004. Groundwater use and salinization with grassland a forestation. Global Change Biology 10:1299-1312.

Jobbágy, E. G., J. M. Paruelo, G. Piñeiro, D. Piñeiro, M. Carámbula, V. Morena, V. Sarli, and A. Altesor. 2005. Climate and land-use controls on ecosystem functioning: challenges and insights from the South. In: Annual report 20032004. San Jose dos Campos, Brazil: Inter-American Institute for Global Change. p. 47-61.

Jobbágy, E. G., M. Vasallo, K. A. Farley, G. Piñelro, M. F. Garbulsky, M. D. Nosetto, R. B. Jackson, and J. M. Paruelo. 2006. Forestación en pastizales: hacia una visión integral de sus oportunidades y costos ecológicos. Agrociencias 10:109-124.

Justice, C. O., J. R. G. Townshend, E. F. Vermote, E. Masuoka, R. E. Wolfe, N. Saleous, D. P. Roy, and J. T. Morisette. 2002. An overview of MODIS Land data processing and product status. Remote Sensing of Environment 83:3-15.

Kirschbaum, M. U. F., L. B. Guo, And R. M. Gifford. 2008. Observed and modelled soil carbon and nitrogen changes after planting a Pinus radiata stand onto former pasture. Soil Biology and Biochemistry 40:247-257.

LAL, R. 2004. Soil carbon sequestration to mitigate climate change. Geoderma 123:1-22.

LAUENROTH, W. K. 1979. Grassland primary production: North American grasslands in perspective. In: N. R. French [ED.]. Perspectives in grassland ecology. Ecological studies, volume 32. New York, NY, USA: Springer-Verlag. p. 3-24.

Lauenroth, W. K. 2000. Methods of estimating belowground net primary production. In: 0. E. Sala [ED.]. Methods in ecosystem science. New York, NY, USA: Springer-Verlag. p. 58-71.

Lauenroth, W. K., H. E. Epstein, J. M. Paruelo, I. C. Burke, M. R. Aguiar, and 0. E. SaLA. 2004. Potential effects of climate change on the temperate zones of North and South America. Revista Chilena de Historia Natural 77:439-453.

McDaniel, P. A., And L. C. Munn. 1985. Effect of temperature on organic carbontexture relationships in Mollisols and Aridisols. Soil Science Society of America Journal 49:1486-1489.

McNaughton, S. J., D. G. Milchunas, and D. A. Frank. 1996. How can net primary productivity be measured in grazing ecosystems? Ecology 77:974-977.

McNaughton, S. J., O. E. Sala, and M. Oesterheld. 1993. Comparative ecology of African and South American arid to subhumid ecosystems. In: P. Goldbarat [ED.]. Biological relationships between Africa and South America. New Haven, CT, USA: Yale University Press. p. 548-567.

Meyer, W. B., and B. L. Turner. 1994. Changes in land use and land cover: a global perspective. Cambridge, United Kingdom: University of Cambridge Press. 513 p.

Milchunas, D. G., and W. K. Lauenroth. 1992. Carbon dynamics and estimates of primary production by harvest, C14 dilution and C14 turnover. Ecology 73:593-607.

Milchunas, D. G., and W. K. Lauenroth. 1993. Quantitative effects of grazing on vegetation and soils over a global range of environments. Ecological Monographs 63:327-366.

Milchunas, D. G., O. E. Sala, and W. K. Lauenroth. 1988. A generalized model of the effects of grazing by large herbivores on grassland community structure. American Naturalist 132:87-106.

MonteITH, J. L. 1972. Solar radiation and productivity in tropical ecosystems. Journal of Applied Ecology 9:747-766.

Mosier, A., D. Schimel, D. Valentine, K. Bronson, and W. J. Parton. 1991. Methane and nitrous oxide fluxes in native, fertilized and cultivated grasslands. Nature 350:330-332.
Nosetto, M. D., E. G. Jobbágy, and J. M. Paruelo. 2005. Land-use change and water losses: the case of grassland afforestation across a soil textural gradient in central Argentina. Global Change Biology 11:1101-1117.

Nouvellon, Y., D. Lo Seen, S. Rambal, A. Begue, M. S. Moran, Y. Kerr, and J. QI. 2000. Time course of radiation use efficiency in a shortgrass ecosystem: consequences for remotely sensed estimation of primary production. Remote Sensing of Environment 71:43-55.

Oesterheld, M., C. Di Bella, And K. Kerdiles. 1998. Relation between NOAA-AVHRR satellite data and stocking rate of rangelands. Ecological Applications 8:207-212.

Oesterheld, M., and R. J. León. 1987. El envejecimiento de las Pasturas Implantadas: su efecto en la productividad primaria. Turrialba 37:29-35.

Oesterheld, M., J. Loreti, M. Semmartin, and J. Paruelo. 1999. Grazing, fire and climate effects on primary productivity of grasslands and savannas. In: L. Walker [ED.]. Ecosystems of disturbed ground. Amsterdam, the Netherlands: Elsevier. p. 287-306.

Oesterheld, M., J. Loreti, M. Semmartin, and 0. E. Sala. 2001. Inter-annual variation in primary production of a semi-arid grassland related to previous-year production. Journal of Vegetation Science 12:137-142.

Oesterheld, M., and S. J. McNaughton. 2000. Herbivory in terrestrial ecosystems. In: 0. E. Sala, R. B. Jackson, H. A. Mooney, and R. W. Howarth [EDs.]. Methods in ecosystem science. New York, NY, USA: Springer. p. 151-157.

Oesterheld, M., O. Sala, and S. J. McNaughton. 1992. Effect of animal husbandry on herbivore-carrying capacity at a regional scale. Nature 356:234-236.

Parton, W. J., D. S. Schimel, and C. V. Cole. 1987. Analysis of factors controlling soil organic matter levels in Great Plains Grasslands. Soil Science Society of American Journal 51:1173-1179.

Paruelo, J. M., H. E. Epstein, W. K. Lauenroth, and I. C. Burke. 1997. AnpP estimates from NDVI for the central grassland region of the United States. Ecology 78:953-958.

Paruelo, J. M., E. G. Jobbágy, M. Oesterheld, R. A. Golluscio, and M. R. Aguiar. 2007. The grasslands and steppes of Patagonia and the Río de la Plata plains. In: T. Veblen and K. Young [EDS.]. The physical geography of South America. Oxford, United Kingdom: Oxford University Press. p. 232249.

Paruelo, J. M., E. Jobbágy, O. E. Sala, W. K. Lauenroth, and I. C. Burke. 1998. Functional and structural convergence of temperate grassland and shrubland ecosystems. Ecological Applications 8:194-206.

Paruelo, J. M., and W. K. Lauenroth. 1996. Relative abundance of plant form types in grasslands and shrublands of North America. Ecological Applications 6:1212-1224.

Paruelo, J. M., W. K. Lauenroth, I. C. Burke, and 0. E. Sala. 1999. Grassland precipitation use efficiency varies across a resource gradient. Ecosystems 2:64-68.

Paruelo, J. M., W. K. Lauenroth, H. Epstein, I. Burke, M. R. Aguiar, and 0. E. Sala. 1995. Regional climatic similarities in the temperate zones of North and South America. Journal of Biogeography 22:2689-2699.

Paruelo, J. M., M. Oesterheld, C. M. Di Bella, M. Arzadum, J. Lafontaine, M. Cahuepé, And C. M. Rebella. 2000. Estimation of primary production of subhumid rangelands from remote sensing data. Applied Vegetation Science 3:189-195.

Paul, K. I., P. J. Polglase, N. J. Nyakuengama, and P. K. Khanna. 2002. Change in soil carbon following afforestation. Forest Ecology and Management 154:395-407.

Perez, C. A., and J. L. Frangi. 2000. Grassland biomass dynamics along an altitudinal gradient in the Pampa. Journal of Range Management 53:518-528.

Piñeiro, G., M. Oesterheld, and J. M. Paruelo. 2006a. Seasonal variation in aboveground production and radiation use efficiency of temperate rangelands estimated through remote sensing. Ecosystems 9:357-373.

Piñeiro, G., J. M. Paruelo, E. Jobbágy, R. Jackson, and M. Oesterheld. 2009. Grazing effects on belowground $\mathrm{C}$ and $\mathrm{N}$ stocks along a gradient of cattle exclosures in temperate and subtropical grasslands of South America. Global Biogeochemical Cycles 23 (in press).

Piñeiro, G., J. M. Paruelo, and M. Oesterheld. 2006b. Potential long-term impacts of livestock introduction on carbon and nitrogen cycling in grasslands of Southern South America. Global Change Biology 12:1267-1284. 
Pizzıo, R. M. 2001. Caracterización y uso del recurso forrajero de la unidad experimental de cría vacuna de la EEA Mercedes. In: Día de Campo: 10 años, Unidad Experimental de Cría Vacuna (1990-2000). Corrientes, Argentina: Instituto Nacional de Tecnología Agropecuaria, Estación Experimental Agropecuaria Mercedes. 113 p.

Platero, H., J. Otero, J. Aguerre, R. Agelaguet, and M. Erramín. 2001. Caracterización de la producción de mejoramientos extensivos con Lotus Rincón en campos de Basalto. In: Utilización y Manejo de Mejoramientos Extensivos con Ovinos. Montevideo, Uruguay: Secretariado Uruguayo de la Lana. p. 42-56.

Potter, C. S., J. T. Randerson, C. B. Field, P. A. Matson, P. M. Vitousek, H. A. Mooney, AND S. A. KLooster. 1993. Terrestrial ecosystem production: a process model based on global satellite and surface data. Global Biogeochemical Cycles 7:811-841.

PRINCE, S. D. 1991. A model of regional primary production for use with coarse resolution satellite data. International Journal of Remote Sensing 12:13131330.

Pucheta, E., I. Bonamici, M. Cabido, and S. Díaz. 2004. Below-ground biomass and productivity of a grazed site and a neighboring ungrazed exclosure in a grassland in central Argentina. Austral Ecology 29:201-208.

Rodríguez, C., E. Leoni, F. Lezama, and A. Altesor. 2003. Temporal trends in species composition and plant traits in natural grasslands of Uruguay. Journal of Vegetation Science 14:433-440.

Rouse, J. W., JR., R. H. HaAs, J. A. Schell, and D. W. Deering. 1973. Monitoring vegetation systems in the great plains with ERTS. In: Proceedings of the 3rd ERTS Symposium, NASA SP-351 1. Washington, DC, USA: US Government Printing Office. p. 309-317.

Ruimy, A., B. Saugier, and G. Dedieu. 1994. Methodology for the estimation of terrestrial net primary production from remotely sensed data. Journal of Geophysical Research 99:5263-5283.

Running, S., P. Thornton, R. Nemani, and J. Glassy. 2000. Global terrestrial gross and net primary productivity from the Earth Observing System. In: 0. E. Sala, R. B. Jackson, H. A. Mooney, and R. W. Howarth [EDS.]. Methods in ecosystem science. New York, NY, USA: Springer. p. 44-57.

Rusch, G. M., and M. Oesterheld. 1997. Relationship between productivity and species and functional group diversity in grazed and non-grazed Pampas grasslands. Oikos 78:519-526.
Sala, O. E., and A. T. Austin. 2000. Methods of estimating aboveground net primary productivity. In: O. E. Sala, R. B. Jackson, H. A. Mooney, and R. W. Howarth [EDs.]. Methods in ecosystem science. New York, NY, USA: Springer. p. 31-43.

Sala, 0. E., V. A. Deregibus, T. Schlichter, and H. Alippe. 1981. Productivity dynamics of a native temperate grassland in Argentina. Journal of Range Management 34:48-51.

Sala, 0. E., W. Parton, L. Joyce, and W. Lauenroth. 1988. Primary production of the central grassland region of the United States. Ecology 69:40-45.

SaldanHA, S. 2005. Manejo del pastoreo en Campos naturales sobre suelos medios de basalto y suelos arenosos de cretácico. In: Seminario de actualización técnica en manejo de campo natural, Montevideo. Montevideo, Uruguay. Serie Técnica INIA 151. p. 75-84.

Scurlock, J. M. 0., K. Johnson, And R. J. OLson. 2002. Estimating net primary productivity from grassland biomass dynamics measurements. Global Change Biology 8:736-753.

Sellers, P. J., J. A. Berry, G. J. Collatz, C. B. Field, and F. G. Hall. 1992. Canopy reflectance, photosynthesis and transpiration III. A reanalysis using improved leaf models and a new canopy integration scheme. Remote Sensing of Environment 42:187-216.

Soriano, A. 1991. Río de la Plata Grasslands. In: R. T. Coupland [ed.]. Natural grasslands: introduction and Western Hemisphere. Amsterdam, the Netherlands: Elsevier. p. 367-407.

't MannetJe, L., AND K. P. HAYDock. 1963. The dry-weight-rank method for the botanical analysis of pasture. Journal of the British Grassland Society 18:268-275.

TUCKER, C. J. 1980. A critical review of remote sensing and other methods for nondestructive estimation of standing crop biomass. Grass and Forage Science $35: 177-182$

Tucker, C. J., J. R. G. Townshend, and T. E. Goff. 1985. African land-cover classification using satellite data. Science 227:369-375.

Verón, S. R., M. Oesterheld, and J. M. Paruelo. 2005. Production as a function of resource availability: slopes and efficiencies are different. Journal of Vegetation Science 16:351-354.

Vitousek, P. M., H. A. Mooney, J. Lubchenco, and J. M. Melillo. 1997. Human domination of Earth's ecosystems. Science 277:494-499.

Wiegand, T., H. A. Snyman, K. Kellner, and J. M. Paruelo. 2004. Do grasslands have a memory: modeling phytomass production of a semiarid South African grassland. Ecosystems 7:243-258. 